\title{
Addition of Capsicum Oleoresin, Carvacrol, Cinnamaldehyde and Their Mixtures to the Broiler Mixed Feed I. Effects On Growth Performance, Carcass Characteristics, Intestinal Microflora, Some Blood Parameters and IGF-1 Gene Expression Levels
}

\author{
Hasan Huseyin Ipcak, (Corresponding author) \\ Department of Animal Science, Faculty of Agriculture, \\ Dicle University, 21280 Sur-Diyarbakir, Turkey \\ E-mail: huseyinipcak@gmail.com \\ Ahmet Alcicek \\ Department of Animal Science, Faculty of Agriculture, \\ Ege University, 35100 Bornova-Izmir, Turkey
}

This article has been prepared from the master's thesis of Hasan Huseyin IPCAK

\begin{abstract}
The aim of this study was to evaluate the effects of dietary capsicum oleoresin (CAP, $150 \mathrm{mg} / \mathrm{kg}$ ), carvacrol (CAR, $150 \mathrm{mg} / \mathrm{kg}$ ), cinnamaldehyde (CIN, $150 \mathrm{mg} / \mathrm{kg}$ ) and equal amount of mixtures (CAP+CAR+CIN, $50 \mathrm{mg} / \mathrm{kg}$ each, capsicum oleoresin + carvacrol + cinnamaldehyde) supplements on growth performance, carcass characteristics, intestinal microflora, some blood parameters and IGF1 gene expression levels in broiler chickens. In the experiment, four hundred Ross-308 day-old, both sexs broiler chicks were randomly distributed to five dietary treatments, each with five replicates. Among these five dietary treatment groups formed for the experiment, the control group was fed without feed additives (control), the second group with $150 \mathrm{mg}$ capsicum oleoresin for each $\mathrm{kg}$ of feed, the third group with 150 $\mathrm{mg}$ carvacrol for each $\mathrm{kg}$ of feed, the fourth group with $150 \mathrm{mg}$ cinnamaldehyde for each $\mathrm{kg}$ of feed, and the last group with $150 \mathrm{mg}$ mixtures for each $\mathrm{kg}$ of feed. The experiment was maintained to six weeks. According to the research results, the effects of dietary treatments on the body weight and the body weight gain were found to be significant $(p<0.05)$. Especially in the group fed on diet added $\mathrm{CAP}+\mathrm{CAR}+\mathrm{CIN}$, the treatments had a significant effect on feed intake and feed conversion ratio as well as body weight and body weight gain when compared to the control group on a periodic basis $(\mathrm{p}<0.05)$. In addition, the effect of the treatments on livability is insignificant $(\mathrm{p}>0.05)$. Among carcass properties, only carcass yield and some organ-related properties were significantly affected from addition of capsicum oleoresin, carvacrol, cinnamaldehyde and their mixtures $(p<0.05)$. Cinnamaldehyde and mixture groups caused to significantly $(\mathrm{p}<0.05)$ reduce AST levels, carvacrol, cinnamaldehyde and capsicum oleoresin groups led to decrease level of triglycerides, carvacrol and mixture groups importantly $(\mathrm{p}<0.05)$ affected LDL levels were detected. And also, especially in the mixture groups, the number of ileum Lactobacillus spp. was found to be significantly higher $(\mathrm{p}<0.05)$ than the other groups. The changes in dietary content were not accompanied by changes in IGF-1 gene expression levels ( $p>0.05$ ). In conclusion, the supplementation carvacrol, cinnamaldehyde, capsicum oleoresin and especially their mixtures at the level of $150 \mathrm{mg} / \mathrm{kg}$ to broiler diets affected positively growth performance, slaughter characteristics, some examined intestinal microflora and blood parameters in broiler chickens.
\end{abstract}

Keywords: Broiler, capsicum oleoresin, carvacrol, cinnamaldehyde

DOI: $10.7176 / \mathrm{JSTR} / 5-12-01$

1 | $\mathrm{P}$ a g e

www.iiste.org 


\section{Introduction:}

Food safety, food reliability and nutrition are leading subjects regarding all world countries recently (Dolekoglu Ozcicek, 2003). Nutrition is one and probably the only essential requirement for individuals in terms of physically, mentally and spiritually healthy and strong living, economic and social development, prosperity, happy, peacefully and safely continuing his existence (Yagmur and Gunes, 2010). It is predicted that for adequate and balanced nutrition, each adult should take $1 \mathrm{~g}$ protein each day per kg of body weight and 42-50 \% of this amount should consist of animal proteins (Kaya, 1996). Another of the most important animal protein sources that should be consumed for physical and mental development and health and balanced nutrition is broiler. Broiler is an important and strategic nutritional source as it has low levels of cholesterol and fat, its digestibility is easy and it is a good protein source in terms of nutritional value thereof and also it is budget friendly compared to some other protein sources (Inci et al., 2014). On the other hand, however, in broiler farming, housing a great number of animals within the coop causes animals to become more vulnerable and unresisting and thus, causes them to be affected easily by immediate condition changes. Until last few years, antibiotics added to rations as development-enhancing feed additive played a remarkable role for the purpose of decreasing risk of animals' getting sick and enabling animals to reach a rapid living weight increase in a short time (Can and Celik, 2008). Nevertheless, as a result of long term use of antibiotics, it has been prohibited to use many antibiotics around the world, particularly European Union countries, as of 2006 because strains resistant to these antibiotics have evolved and risk of resistance formation has appeared (Simsek et al., 2005). Thus, researchers have started seeking a natural and safe development stimulating material as growth factor that may maintain these developments experienced during use of antibiotics in poultries and that may be alternative to overcome negativities that may occur in absence of antibiotics. (Alcicek, 2003; Ceylan et al., 2003). For this purpose, aromatic plants and essential oils derived from these plants and primary active ingredients thereof are used in pharmaceutical, cosmetics and feed fields due to many features such as antibacterial, antioxidant, antiviral, antifungal and digestive system-stimulating feature and its utilisation in animal feeding field is also gaining currency (Can and Celik, 2008). Research conducted by Al-Kassie (2009), investigated the effects of 100 and 200 ppm cinnamon and thyme oil addition to the mixed feed of broiler chicks (Arbor Acres) on body weight gain, feed intake, feed conversion rate and blood constituents, and thus revealed that the body weight gain and feed intake was higher; feed conversion rate was better and serum cholesterol levels were lower in 200 ppm group compared to the control group. Khattak et al. (2014), studied the effect of commercial essential oil mix (basil+caraway+laurel+lemon+oregano+ sage+tea and thyme) addition to mixed feed at different doses; i.e, 0-100-200-300-400-500 g/t, on performance, carcass weight, intestinal activity and blood biochemistry of broiler chicks (Ross, 308); and concluded that the body weight and carcass weight increased in accordance with the dosage, however no difference was observed among groups regarding blood biochemistry and intestinal activity. Sharifi et al. (2013), respectively added 15, 3, 2 and $2 \mathrm{~g} / \mathrm{kg}$ of four different aromatic leaves in dried form (Cumin, peppermint, yarrow and poley-haired herba chamaedrys) to broiler chicks' (Arbor Acres) mixed feed, and investigated related effects on performance and blood constituents. $0.4 \mathrm{~g} / \mathrm{kg}$ Flavomycin group was formed as the positive control. The experiment revealed that the body weight and triglyceride levels were lower in aromatic plant mixture group; that the total cholesterol levels increased in the group where cumin and peppermint were added; whereas it decreased in the group where yarrow and poley was added. It was stated that HDL and LDL values differed (increased or decreased) at different rates among different groups. It was observed that the Bifidobacterium and Clostridium perfringens (log 10/g) levels decreased in all groups except for the cumin group, whereas Lactobacillus spp. and Coliform levels remained the same. Research conducted regarding the subject suggests that the addition of various plant extracts enhanced the body weight gain Al-Mashhadani et al. 2011a, b); and the feed conversion rate (Jamroz et al. 2005), however had no effect on carcass characteristics (Şimşek et al. 2005; Kırkpınar et al. 2014); and on blood plasma lipids such as total cholesterol, trigylcerides and HDL cholesterol (Lee et al. 2004; Nafaji and Torki 2010); reduced the Escherichia Coli count in the intestines (Shanoon et al. 2012; Hashemipour et al. 2013) and on the other hand boosted the Lactobacillus spp. and Bifidobacterium counts in broiler chicks (Hashemipour et al., 2013). It should further be considered that the composition and quantity of essential oils obtained from different organs (root, stem, flower, etc.) and in different growth stages of plants growing under different climatic conditions might differ accordingly. This difference challenges the determination of effective dose of the plant itself or the essential oils to be used directly as feed additives. Hence, usage of primary active ingredients isolated from volatile essential oils is favored as feed additives (Kahraman, 2015). Consequently, following constituents were used for the purpose of this research: carvacrol and cinnamaldehyde for their appetite enhancing characteristics, along with their antimicrobial and antifungal

2 | P a g e www.iiste.org 
properties (Saad et al., 2013; Kahraman, 2015); capsicum oleoresin for its endocrine and immune system stimulating (Jamroz et al., 2005; Catala-Gregori et al., 2008) and antioxidizing (Viktorija et al., 2014) properties; and lastly the combination group for the assumption of synergetic effects of various combinations of the above mentioned active ingredients (Nevvcomb, 1999). This study aims to investigate and determine the effects of the addition of synthesized, commercially available (and intended antibiotic alternatives) $150 \mathrm{mg} / \mathrm{kg}$ carvacrol, cinnamaldehyde, naturally obtained capsicum oleoresin, and the mixtures containing equal amounts of them $(50 \mathrm{mg} / \mathrm{kg}$ capsicum oleoresin $+50 \mathrm{mg} / \mathrm{kg}$ carvacrol $+50 \mathrm{mg} / \mathrm{kg}$ cinnamaldehyde) to the mixed feeds of broiler chickens on performance characteristics (body weight, body weight gain, feed intake and feed conversion ratio), livability, carcass characteristics (carcass yield, breast ratio, leg ratio and abdominal fat ratio), organ weights, intestinal microflora, some blood parameters and IGF1 gene expression.

\section{Materials and Methods}

Chicks, Experimental Design and Diets: In the study, 400 daily mixed gender broiler chicks (Ross-308) were used as animal material. Chicks were purchased from a commercial hatchery (EGETAV). Experiment was conducted in a total of 5 groups, 1 control and 4 treatment groups. Each group was again divided into 5 groups, each containing 16 chicks. Crumble feed material used in the study was obtained from a commercial feed company. Rations used in the study were prepared in accordance with nutrient requirements stated in NRC (1994). During study, chicks were given broiler chick feed from day 1 to day 21 and broiler grower feed from day 22 to slaughter day (day 42). Compositions and nutrient contents of mixed feeds used in the study were given in Table 1. Ration of control group was prepared not to contain any additives. First treatment group ration was prepared by daily $150 \mathrm{mg} / \mathrm{kg}$ capsicum oleoresin addition to control group ration, second treatment group ration was prepared to contain daily $150 \mathrm{mg} / \mathrm{kg}$ carvacrol, third treatment group ration was prepared by daily $150 \mathrm{mg} / \mathrm{kg}$ cinnamaldehyde addition and fourth treatment group ration was fed with crumble feeds containing $150 \mathrm{mg}$ mixture $(50 \mathrm{mg}$ each, capsicum oleoresin + carvacrol + cinnamaldehyde). To provide feed homogeneous mixture of carvacrol, cinnamaldehyde and capsicum oleoresin, firstly premixture with zeolite $(\mathrm{g} / \mathrm{kg})$ was prepared and then this mixture was added to main mixture (to crumble feed). In the study, synthetically obtained and commercially sold $99 \%$ carvacrol, $98 \%$ cinnamaldehyde, $99 \%$ capsicum oleoresin and mixture thereof were used. Carvacrol, cinnamaldehyde and capsicum oleoresin level added to mixed feeds were determined in parallel with levels stated in studies (Eldeeb et al., 2006; Lee et al., 2003a; 2003b) pertaining to various effective materials and essential oils in poultries.

Chicks Housing and Management: Group feeding was applied for animals in each compartment (1.2 m $\mathrm{x} 1.1=1.32 \mathrm{~m}^{2}$ ), feed and water were presented ad libitum. Wood flour was used as base in the experiment and the study was carried out in environmentally controlled closed experiment coops in Facilities of Animal Science Department, Faculty of Agricultural, Ege University. In the first week of experimental chick feeder and waterer were used and then suspended bucket type round feeder and automatic suspended waterers were used. During the course of experiment 23-hour-light and 1-hour dark plan (day light and ampoules) was applied. It was noted to keep ambient temperature in chick level at $34{ }^{\circ} \mathrm{C}$ during the first 5 days and this temperature was dropped to until minimum $23{ }^{\circ} \mathrm{C}$ gradually on other days of the study. During the trial animals were monitored daily and death/deaths were recorded. Experiment was maintained for 6 weeks.

Feed material Analaysis: The amount of nutrients in the broiler feed (apart from cellulose) used in the study was determined according to Weende analysis method (Naumann and Bassler, 1993), whereas raw cellulose was determined according to Lepper method (Bulgurlu and Ergul, 1978). Additionally, metabolical energy content was calculated using the regression equation recommended by TSI (Turkish Standards Institute) standard No. 9610 (TSI, 1994).

Performance: The animals have been weighted individually at the same day and same hour once every week in the days of 7., 14., 21., 28., 35. and 42 of trial and beginning of the experiment with an objective to determine the characteristics of the performance and consumption of feed of each sub group have been recorded. The feed conversion ratio has been calculated by dividing feed intake values determined between 0-7, 7-14, 14-21, 21-28, 28-35 and 35-42 days of each sub group by the body weights gained in these terms. Necessary adjustments have been made in calculations as per the compartment occupancy of deceased animals and the feed amount consumed by such.

3| P a g e www.iiste.org 
Carcass Characteristics:_Fifty animal in total, 5 females and 5 males from each group, each 1 male and 1 female has been selected randomly from the repetition in the 42th day of the experiment have been slaughtered by shedding blood and plucking and their heads and foots are separated. After that, their internal organs and abdominal fat have been removed and hot carcass has been weighted and leg (from Art. coxea) and breast (Art. sternocostalisten) meat have been separated from the carcass. Carcass parts have been weighted without skin to specify the carcass features on the date of slaughter and the results have been proportioned to the body weight (\%) and it's been given by proportional values. The carcass yield has been calculated by proportioning the hot carcass weight to the body weight.

Table 1. Ingredients and chemical composition of experimental diets (as-fed basis)

\begin{tabular}{|c|c|c|}
\hline Feed stuff, $\%$ & $\begin{array}{l}\text { Broiler chick } \\
(0-21 . \text { Days })\end{array}$ & $\begin{array}{c}\text { Broiler } \\
(22-42 . \text { Days })\end{array}$ \\
\hline Corn & 46.96 & 48.91 \\
\hline Soybean meal & 20.88 & 12.37 \\
\hline Wheat & 0.00 & 5 \\
\hline Full-fat soybean & 14.57 & 15 \\
\hline Corn bran & 4.5 & 3 \\
\hline Sunflower seed meal $34 \% \mathrm{CP}$ & 4 & 4.5 \\
\hline DDGS & 2.5 & 3 \\
\hline Poultry meal & 2.29 & 4 \\
\hline Marble powder & 1.12 & 0.93 \\
\hline DCP $18 \%$ & 1.08 & 0.71 \\
\hline Lysine sulfate $70 \%$ & 0.51 & 0.46 \\
\hline Commerical fat & 0.5 & 1.15 \\
\hline Commerical methionine & 0.32 & 0.23 \\
\hline${ }^{1}$ Vitamin premix-001 & 0.2 & 0.00 \\
\hline${ }^{2}$ Vitamin premix-002 & 0.00 & 0.2 \\
\hline Salt & 0.19 & 0.16 \\
\hline Sodium sulfate & 0.12 & 0.10 \\
\hline${ }^{3}$ Mineral & 0.10 & 0.1 \\
\hline L-threonine & 0.06 & 0.04 \\
\hline Liquid choline $75 \%$ & 0.06 & 0.06 \\
\hline Coccidiostat & 0.05 & 0.05 \\
\hline \multicolumn{3}{|l|}{ Calculated values, $g / \mathrm{kg}$} \\
\hline Metabolizable energy, kcal/kg & 3025 & 3150 \\
\hline Lysine & 14.57 & 12.72 \\
\hline Methionine + cystine & 10.97 & 9.99 \\
\hline Avaliable P & 5.00 & 4.5 \\
\hline \multicolumn{3}{|l|}{ Composition (analysed), $\mathrm{g} / \mathrm{kg}$} \\
\hline Dry matter & 880.29 & 880.85 \\
\hline Crude protein & 237.65 & 217.67 \\
\hline Ether extract & 56.96 & 66.06 \\
\hline Crude ash & 59.73 & 52.69 \\
\hline Crude fiber & 37.06 & 36.70 \\
\hline Calcium & 10.50 & 9.00 \\
\hline Total phosphorus & 6.40 & 5.69 \\
\hline Starch & 344.30 & 376.12 \\
\hline Sugar & 41.24 & 35.65 \\
\hline
\end{tabular}


${ }^{1}$ Vitamin premix-001 per kg diet: 11000 IU Vitamin A; 5000 IU Vitamin $\mathrm{D}_{3} ; 0.069 \mathrm{mg}$ 25-OH-D 3 ; 150 mg Vitamin E; $3 \mathrm{mg}$ Vitamin $\mathrm{K}_{3} ; 3 \mathrm{mg}$ Vitamin $\mathrm{B}_{1 ;} 8 \mathrm{mg}$ Vitamin $\mathrm{B}_{2} ; 4 \mathrm{mg}$ Vitamin $\mathrm{B}_{6 ;} 0.02 \mathrm{mg}$ Vitamin $\mathrm{B}_{12} ; 60 \mathrm{mg}$ Niacin; $15 \mathrm{mg}$ D-Pantothenic; $2 \mathrm{mg}$ Folic acid; $0.2 \mathrm{mg}$ Biotin; $100 \mathrm{mg}$ Vitamin C; $400 \mathrm{mg}$ choline,

${ }^{1}$ Vitamin premix-002 per kg diet: There are 10000 IU Vitamin A; 5000 IU Vitamin $\mathrm{D}_{3} ; 0.069 \mathrm{mg} 25-\mathrm{OH}-$ $\mathrm{D}_{3} ; 50 \mathrm{mg}$ Vitamin $\mathrm{E} ; 3 \mathrm{mg}$ Vitamin $\mathrm{K}_{3} ; 3 \mathrm{mg}$ Vitamin $\mathrm{B}_{1} ; 8 \mathrm{mg}$ Vitamin $\mathrm{B}_{2} ; 4 \mathrm{mg}$ Vitamin $\mathrm{B}_{6} ; 0.02 \mathrm{mg}$ Vitamin $\mathrm{B}_{12}$; $60 \mathrm{mg}$ Niacin; $12 \mathrm{mg}$ D-Pantothenic; $2 \mathrm{mg}$ Folic acid; $0.2 \mathrm{mg}$ Biotin; $100 \mathrm{mg}$ Vitamin C; $400 \mathrm{mg}$ choline,

${ }^{3}$ Mineral per kg diet: $150 \mathrm{~g} \mathrm{Mn}, 120 \mathrm{~g} \mathrm{Fe}, 150 \mathrm{~g} \mathrm{Zn}, 14 \mathrm{~g} \mathrm{Cu}, 0,4 \mathrm{~g} \mathrm{Co}, 3 \mathrm{~g} \mathrm{Se}$.

Organ Weights: On the 42th day of the experiment, the animals that are selected with an objective to specify the carcass features are slaughtered and liver, heart, spleen, pancreas, bursa fabricius, grandual stomach, gizzard, small intestine, cecum and large intestine have been taken our carefully and weighted at the $0.01 \mathrm{~g}$ sensitive balance. The data has been proportionated to body weight $(\%)$ and they are calculated in proportional values and the results have been given in such way.

Intestinal Microflora and Some Blood Analaysis: At the end of the study (day 42), 4-5 cc of blood was taken to heparin-containing tubes from brachial veins of 50 animals ( 2 animal/repetition, 10 animal/treatment group). Blood samples were transferred to respective laboratories by separating serums by 20 minute centrifugation in $4000 \mathrm{rpm}$ in a ventilated centrifuge $\left(+4^{\circ} \mathrm{C}\right)$. Biochemical parameters of Alanine Transaminase (ALT), Aspartate Transaminase (AST), albumin, total protein, glucose, triglyceride, total cholesterol, High Density Lipoprotein (HDL) and Low Density Lipoprotein (LDL) levels were spectrophotometrically detected using related commercials kits (Roche cobas 501). For microbiological analyses, intestines of animals were quickly removed and the ileum part of the small intestines was separated. The ileum samples taken for microbiological analyses were transferred to the Directorate of Bornova Veterinary Control Institute Poultry Disease Diagnostic Laboratory in an icebox preserving the $+4{ }^{\circ} \mathrm{C}$ temperature condition and a Salmonella spp. positive/negative test was performed on the ileum samples (TSI, 2005a). The samples were shortly delivered to the Ege University Microbiological Analysis Laboratory (EGEMIKAL) for Clostridium perfringens, Staphylococcus aureus and Lactobacillius spp. counts in the ileum content. The Lactobacillius spp. count was performed by ISO 15214, the Staphylococcus aureus detection was performed by ISO 6888-1 (ISO, 1998a; 1998b), the Salmonella spp. positive/negative test was performed by ISO 6579 and the Clostridium perfringens detection was performed by the ISO 7937 method (TSI, 2005a; 2005b).

Sample Collection, Total RNA and cDNA Isolation:_At the end of the study (42 days), to specify the expression level of the IGF 1 gene, 4-5 cc blood have been taken from the brachial vein of the 50 animals in total ( 2 animals/repeated, 10 animals/treatment group) to the EDTA tubes. The samples have been brought to the lab within an ice bag lymphocyte separation has been conducted for RNA isolation from the whole blood. Total RNA was isolated from each blood sample using the RNeasy Mini Kit (QIAGEN) according to the manufecturer's protocal. Total RNA was quantified spectrophotometrically at 260/280 $\mathrm{nm}$ and stored at $-80{ }^{\circ} \mathrm{C}$. The reverse transcription (RT) was carried out following the RT First Strand Kit (QIAGEN) protocol (QIAGEN, 2013).

Primer Design, Sample Loading and Quantification of Gene Expression by Real Time PCR: To design the primers, related studies have rewiewed and showed that all consequences were compared to NCBI data center ( $\mathrm{Lu}$ et al., 2009; MacKinnon et al., 2009). The primer and genbank accession numbers of the target genes are included in Table 2. Expression of Insulin Like Growth Factor-1 (IGF-1) and a housekeeping gene, glyceraldehyde 3-phosphate dehydrogenase (GAPDH), were determined in blood by quantitative RT-PCR. For each sample, reaction mixture for both IGF1 gene and also GADPH gene that we used as a reference housekeeping gene were prepared by mixing $12.5 \mu 12 \mathrm{x} \mathrm{RT}^{2} \mathrm{SYBR}_{\text {Green }}$ Mastermix, $1 \mu \mathrm{l} \mathrm{RT}{ }^{2}$ qPCR Primer Assay (10 $\mu \mathrm{M}$ stock solution) and $10.5 \mu 1$ RNase-free water in a microcentrifuge tube of $1.5 \mathrm{ml}$. In each well, $24 \mu \mathrm{l}$ of reaction mixture and $1 \mu \mathrm{l}$ of DNA sample was mixed to achieve a total volume of $25 \mu$ l. Samples prepared in this way were placed in Rotorgene Corbett Research device. Replication curves were simultaneously followed from the device monitor. Data analysis was performed using the software in analysis subsection of the online website: http://www.sabiosciences.com. In addition to graphical expression of the results, evaluation was made with comparative threshold $\left(\mathrm{C}_{\mathrm{T}}\right)$ method. In this method, initially the $\mathrm{C}_{\mathrm{T}}$ values of samples from both treatment and control groups were calculated for each of the GADPH and IGF1. Then, GAPDH $\mathrm{C}_{\mathrm{T}}$ value

5 I $\mathrm{P}$ a g e www.iiste.org 
was subtracted from the IGF1 $\mathrm{C}_{\mathrm{T}}$ value to calculate the $\Delta \mathrm{C}_{\mathrm{T}}$ (Delta $\mathrm{C}_{\mathrm{T}}$ ) value in each of the treatment and control groups. Then, mean $\Delta \mathrm{C}_{\mathrm{T}}$ value of the control group was subtracted from the mean $\Delta \mathrm{C}_{\mathrm{T}}$ value of the treatment group in order to determine the $\Delta \Delta \mathrm{C}_{\mathrm{T}}$ value. This value was applied to the formula $2^{-\Delta \Delta \mathrm{Ct}}$ in order to determine the relative folds of increase or decrease of IGF1 gene expression in the treatment group in comparison to the control group, while taking GADPH gene expression as the internal control (ABI PRISM 7700, 1997). $\Delta \mathrm{C}_{\mathrm{T}}$ ve $\Delta \Delta \mathrm{C}_{\mathrm{T}}$ values were calculated as follows:

$$
\begin{gathered}
\Delta \mathrm{C}_{\mathrm{T}, \text { Control }}=\left(\text { Control }_{I G F 1}-\text { Control }_{\text {GAPDH }}\right) \\
\Delta \mathrm{C}_{\mathrm{T}, \text { Treatment }}=\left(\text { Treatment }_{I G F 1}-\text { Treatment }_{G A P D H}\right) \\
\Delta \Delta \mathrm{C}_{\mathrm{T}, \text { Treatment }}=\text { with respect to control }=\left(\Delta \mathrm{C}_{\mathrm{T}, \text { Treatment }}-\Delta \mathrm{C}_{\mathrm{T}, \text { Control }}\right)
\end{gathered}
$$

Fold expression with respect to control $=2^{-\Delta \Delta C_{T}}$

Table 2. Real-time RT-PCR primer and Genbank accession numbers of the target genes.

\begin{tabular}{llll}
\hline $\begin{array}{l}\text { Target } \\
\text { Gene }\end{array}$ & Forward primer $\left(\mathbf{5}^{\prime} \rightarrow \mathbf{3}^{\prime}\right)$ & Reverse primer $\left(\mathbf{5}^{\prime} \rightarrow \mathbf{3}^{\prime}\right)$ & $\begin{array}{l}\text { Genbank } \\
\text { Accession }\end{array}$ \\
\hline GAPDH & GGGCACGCCATCACTATCTTC & ACCTGCATCTGCCCATTTGAT & NM_204305 \\
IGF-I & GTATGTGGAGACAGAGGCTTC & TTTGGCATATCAGTGTGGCGC & NM_001004384 \\
\hline
\end{tabular}

Statistical analyses: Statistical analyses of data obtained was performed in SPSS 21,0 (Inc., Chicago, II, USA) program. One-way variance analysis (ANOVA) was applied for difference between statistical calculations of groups and mean values of groups and Duncan test for significance of difference among groups and significance levels $(\mathrm{p}<0.05)$ were determined (SPSS, 2012). Findings, means of groups and standard deviation of differences among groups and significance level (p) obtained at the end of the study are presented in tables.

\section{Results and Discussion}

\subsection{Growth Performance}

Considering Table 3, it may be seen that there was no significant difference among the experiment groups in terms of body weight $(\mathrm{BW})$ in the first week and the $14^{\text {th }}$ day of the trial $(\mathrm{p}>0.05)$; and there was a significant difference in the $7^{\text {th }}, 21^{\text {st }}, 28^{\text {th }}, 35^{\text {th }}$, and $42^{\text {nd }}$ days $(\mathrm{P}<0.05)$. In the $7^{\text {th }}$ day, the highest mean body weight of the chicks was reached both in the CAP+CAR+CIN group and the CAP group, while only the CAP+CAR+CIN group reached it in the $21^{\text {st }}, 28^{\text {th }}, 35^{\text {th }}$, and $42^{\text {nd }}$ days. At the end of the trial, it was seen that the CAP+CAR+CIN experiment group had a higher mean body weight than the control group and the other experiment groups. In the $42^{\text {nd }}$ day, the experiment group fed with a $150 \mathrm{mg} / \mathrm{kg}$ daily addition of $\mathrm{CAP}+\mathrm{CAR}+\mathrm{CIN}$ to the feed had gained $4.6 \%$ more body weight than the control group. Considering previous studies on the effects of essential oils and main components on body weight, there were conflicts. Accordingly, it was stated by Fotea et al. (2010) that addition of $1 \%$ carvacrol in the 0 $42^{\text {nd }}$ days, by Al Mashhadani et al. (2011a) that addition of $200 \mathrm{mg} / \mathrm{kg}$ thyme $+200 \mathrm{mg} / \mathrm{kg}$ anise in the 28-38 th days and by Awaad et al. (2014) that addition of $100 \mathrm{~g} /$ ton CAP+CAR+CIN (+111 g) improved live weight significantly. According to Kucukyılmaz et al. (2012), addition of a commercial mixture containing thyme by $48 \mathrm{mg} / \mathrm{kg}$ in the $0-42^{\text {nd }}$ days, and according to Celikbilek et al. (2014), addition of a commercial oil mixture by $2 \mathrm{~g} / \mathrm{kg}$, did not create an effect on body weight. Nafaji and Torki (2010) found that addition of cinnamon oil to the ration did not change live weight in the $0-21^{\text {st }}$ days and the 43 $49^{\text {th }}$ days, but reduced it in the $23-42^{\text {nd }}$ days. 
Table 3. The effect of the capsicum oleoresin, carvacrol, cinnamaldehyde and their mixture added to the compound feed of broiler on body weights, $\mathrm{g}(\mathrm{x} \pm \mathrm{SEM})$.

a,b,c: The differences between means in the same row with different letters are important, $\mathrm{p}<0.05$

\section{Treatment Groups}

\begin{tabular}{lllllll} 
Day & Control & CAP & CAR & CIN & CAP+CAR+CIN & P \\
\hline $\mathbf{0}$ & $33.83 \pm 0.31$ & $33.97 \pm 0.30$ & $34.13 \pm 0.32$ & $33.99 \pm 0.36$ & $33.68 \pm 0.23$ & 0.0871 \\
$\mathbf{7}$ & $139.00 \pm 1.69^{\mathrm{c}}$ & $154.47 \pm 1.65^{\mathrm{a}}$ & $142.53 \pm 1.63^{\mathrm{c}}$ & $145.16 \pm 1.96^{\mathrm{b}}$ & $158.27 \pm 1.42^{\mathrm{a}}$ & 0.000 \\
$\mathbf{1 4}$ & $439.49 \pm 4.26$ & $442.36 \pm 5.38$ & $443.11 \pm 4.81$ & $436.73 \pm 5.15$ & $445.10 \pm 4.25$ & 0.760 \\
$\mathbf{2 1}$ & $927.75 \pm 9.05^{\mathrm{ab}}$ & $924.11 \pm 10.26^{\mathrm{ab}}$ & $918.30 \pm 9.79^{\mathrm{b}}$ & $903.077 \pm 10.07^{\mathrm{b}}$ & $949.14 \pm 9.92^{\mathrm{a}}$ & 0.024 \\
$\mathbf{2 8}$ & $1578.58 \pm 16.72^{\mathrm{ab}}$ & $1547.20 \pm 18.43^{\mathrm{b}}$ & $1523.38 \pm 18.80^{\mathrm{b}}$ & $1558.75 \pm 20.83^{\mathrm{ab}}$ & $1606.04 \pm 18.18^{\mathrm{a}}$ & 0.025 \\
$\mathbf{3 5}$ & $2323.83 \pm 30.05^{\mathrm{ab}}$ & $2303.47 \pm 31.56^{\mathrm{ab}}$ & $2232.67 \pm 31.43^{\mathrm{b}}$ & $2287.48 \pm 33.44^{\mathrm{ab}}$ & $2365.00 \pm 28.56^{\mathrm{a}}$ & 0.046 \\
$\mathbf{4 2}$ & $2992.18 \pm 40.83^{\mathrm{b}}$ & $2988.73 \pm 41.42^{\mathrm{b}}$ & $2910.42 \pm 43.00^{\mathrm{b}}$ & $2967.80 \pm 45.51^{\mathrm{b}}$ & $3130.78 \pm 39.61^{\mathrm{a}}$ & 0.005
\end{tabular}

Considering Table 4, the differences among the groups in terms of the mean body weight gains (BWG) were not found statistically significant in the $7-14^{\text {th }}$ and the $28-35^{\text {th }}$ days $(\mathrm{P}>0.05)$, while they were significant in the $14-21^{\text {st }}$, the $21-28^{\text {th }}$, and the $35-42^{\text {nd }}$ days $(\mathrm{P}<0.05)$. According to the obtained findings, the highest mean BWG was found in the CAP+CAR+CIN and CAP groups between the $1^{\text {st }}$ and the $7^{\text {th }}$ days, and in the CAP+CAR+CIN, control and CIN groups in the 21-28 $8^{\text {th }}$ days. The highest BWG was seen only in the $\mathrm{CAP}+\mathrm{CAR}+\mathrm{CIN}$ in the $14-21^{\text {st }}$ and the $35-42^{\text {nd }}$ days. According to the findings regarding the BWG means computed for periods, the differences among the experiment groups in the $0-21^{\text {st }}, 22$ $42^{\text {nd }}$ and $0-42^{\text {nd }}$ days were significant $(\mathrm{p}<0.05)$, while the highest BWG was seen in the CAP+CAR+CIN group. It was found that addition of $150 \mathrm{mg} / \mathrm{kg} \mathrm{CAP}+\mathrm{CAR}+\mathrm{CIN}$ into the feed in the $0-42^{\text {nd }}$ days increased the mean BWG by $4.3 \%$ in comparison to the control group. Accordingly, the results obtained from the study agreed with those of other studies. Awaad et al. (2014) reported that a $100 \mathrm{~g} / \mathrm{ton}$ addition of CAP $(2.18 \%)+$ CAR $(5.04 \%)+$ CIN $(2.90 \%)$ reduced the BWG in comparison to the control in a 1-week period, did not change it in a period of 1-3 weeks, and increased it in a period of 3-5 weeks. Bravo et al. (2011) reported that, the CAR (5\%) + CIN (3\%) + CAP (2\%) mixture was not effective by $100 \mathrm{mg} / \mathrm{kg}$ combination in 1-22 ${ }^{\text {nd }}$ days on BWG, while Karadas et al. (2014) found that addition of the same mixture and dosage to the feed increased BWG by $86 \mathrm{~g}$ in comparison to the control in the period of $0-21^{\text {st }}$ days. According to Babaoglan and Kutlu (2008), addition of natural or synthetic thymol:carvacrol in the ratio of 1:1, and according to Alcicek et al. (2004), addition of a commercial essential oil mixture containing thyme by $48 \mathrm{mg} / \mathrm{kg}$ improved BWG in comparison to control; while Lee et al. (2004) reported that addition of 200 ppm CAR into the feed decreased it by $4.6 \%$. 
Table 4. The effect of the capsicum oleoresin, carvacrol, cinnamaldehyde and their mixture added to the compound feed of broiler on body weight gain, $\mathrm{g}(\mathrm{x} \pm \mathrm{SEM})$.

\begin{tabular}{lllllll}
\hline & \multicolumn{5}{c}{ Treatment Groups } \\
\cline { 2 - 7 } Day & Control & CAP & CAR & CIN & CAP + CAR + & P \\
\hline $\mathbf{0 - 7}$ & $105.24 \pm 2.74^{\mathrm{b}}$ & $119.06 \pm 3.01^{\mathrm{a}}$ & $109.11 \pm 1.81^{\mathrm{b}}$ & $105.00 \pm 3.69^{\mathrm{b}}$ & $124.71 \pm 1.57^{\mathrm{a}}$ & 0.000 \\
$\mathbf{7 - 1 4}$ & $300.47 \pm 3.51$ & $289.34 \pm 3.61$ & $300.58 \pm 5.26$ & $292.92 \pm 4.94$ & $286.83 \pm 4.14$ & 0.118 \\
$\mathbf{1 4 - 2 1}$ & $488.26 \pm 3.85^{\mathrm{b}}$ & $481.63 \pm 5.11^{\mathrm{b}}$ & $475.19 \pm 5.30^{\mathrm{b}}$ & $477.22 \pm 7.04^{\mathrm{b}}$ & $506.17 \pm 4.26^{\mathrm{a}}$ & 0.003 \\
$\mathbf{2 1 - 2 8}$ & $650.82 \pm 7.73^{\mathrm{a}}$ & $622.98 \pm 10.88^{\mathrm{ab}}$ & $605.49 \pm 13.30^{\mathrm{b}}$ & $644.99 \pm 10.64^{\mathrm{a}}$ & $654.89 \pm 8.51^{\mathrm{a}}$ & 0.014 \\
$\mathbf{2 8 - 3 5}$ & $745.25 \pm 29.95$ & $756.12 \pm 17.29$ & $709.15 \pm 21.91$ & $730.12 \pm 24.86$ & $759.21 \pm 10.03$ & 0.488 \\
$\mathbf{3 5 - 4 2}$ & $685.58 \pm 34.09^{\mathrm{b}}$ & $697.57 \pm 30.00^{\mathrm{ab}}$ & $672.60 \pm 18.88^{\mathrm{b}}$ & $657.51 \pm 34.69^{\mathrm{b}}$ & $772.10 \pm 8.04^{\mathrm{a}}$ & 0.000 \\
\hline $\mathbf{0 - 2 1}$ & $879.47 \pm 3.18^{\mathrm{b}}$ & $890.02 \pm 5.58^{\mathrm{b}}$ & $884.17 \pm 8.73^{\mathrm{b}}$ & $891.13 \pm 10.75^{\mathrm{b}}$ & $917.61 \pm 8.05^{\mathrm{a}}$ & 0.030 \\
$\mathbf{2 2 - 4 2}$ & $2081.65 \pm 45.92^{\mathrm{b}}$ & $2076.68 \pm 36.36^{\mathrm{b}}$ & $1987.23 \pm 24.87^{\mathrm{b}}$ & $2050.62 \pm 14.28^{\mathrm{b}}$ & $2186.21 \pm 17.73^{\mathrm{a}}$ & 0.003 \\
$\mathbf{0 - 4 2}$ & $2975.63 \pm 48.23^{\mathrm{b}}$ & $2966.70 \pm 38.17^{\mathrm{bc}}$ & $2871.41 \pm 27.96^{\mathrm{c}}$ & $2930.40 \pm 12.79^{\mathrm{bc}}$ & $3103.82 \pm 21.56^{\mathrm{a}}$ & 0.001 \\
\hline
\end{tabular}

a,b,c: The differences between means in the same row with different letters are important, $\mathrm{p}<0.05$

Considering Table 5, while there was no statistically significant difference among group in terms of feed intake in the $7-14^{\text {th }}, 21-28^{\text {th }}$ and $35-42^{\text {nd }}$ days ( $\left.p>0.05\right)$; the difference was significant in the $0-7^{\text {th }}, 14-21^{\text {st }}$ and $28-35^{\text {th }}$ days $(\mathrm{p}<0.05)$. The highest feed intake value in the $0-7^{\text {th }}$ days was found in the control and CAP group, while it was found in the CAP+CAR+CIN group in the $14-21^{\text {st }}$ and $28-35^{\text {th }}$ days. Considering periods of the $0-21^{\text {st }}, 22-42^{\text {nd }}$ and $0-42^{\text {nd }}$ days, the trial had significant effects on feed intake $(\mathrm{p}<0.05)$, while the highest consumption was found to be in the CAP+CAR+CIN group. At the end of the trial ( $42^{\text {nd }}$ day), while the CAP+CAR+CIN experiment group had a mean per-animal feed intake that is 53.28 higher than that of the control group, the difference was not significant ( $p>0.05)$. Finding the feed intake rates among groups significantly difficult was explained by, essential oils reducing pathogenic bacteria population and improving intestinal microflora (Alcicek et al., 2004), stimulating effects on the digestive system (Mukhtar, 2011) and appetizing effects (Babaoglan, 2008). It was reported by Fotea et al. (2010) that $1 \%$ carvacrol addition and by Al-Mashdani et al. (2011b) that $1 \%$ coriander oil increased feed intake; it was reported by Babaoglan (2008) that thymol/carvacrol addition and by Mukhtar (2011) that 400 $\mathrm{mg} / \mathrm{kg}$ clove oil addition did not affect feed intake rates; while Akyurek and Yel (2011) stated that addition of $250 \mathrm{mg} / \mathrm{kg}$ thymol $+250 \mathrm{mg} / \mathrm{kg}$ carvacrol reduced the rate of feed intake. 
International Journal of Scientific and Technological Research

ISSN 2422-8702 (Online), DOI: 10.7176/JSTR/5-12-01

Vol.5, No.12, 2019

Table 5. The effect of the capsicum oleoresin, carvacrol, cinnamaldehyde and their mixture added to the compound feed of broiler on feed intake, g ((animal/day), $\mathrm{x} \pm \mathrm{SEM})$.

\begin{tabular}{lllllll}
\hline & \multicolumn{5}{c}{ Treatment Groups } \\
\cline { 2 - 7 } Day & Control & CAP & CAR & CIN & CAP + CAR + & P \\
\hline $\mathbf{0 - 7}$ & $173.81 \pm 2.53^{\mathrm{a}}$ & $170.57 \pm 3.30^{\mathrm{a}}$ & $147.32 \pm 2.33^{\mathrm{c}}$ & $156.28 \pm 6.27^{\mathrm{bc}}$ & $165.35 \pm 6.63^{\mathrm{b}}$ & 0.004 \\
$\mathbf{7 - 1 4}$ & $319.84 \pm 5.62$ & $325.40 \pm 4.45$ & $327.34 \pm 6.21$ & $322.43 \pm 6.20$ & $324.16 \pm 4.10$ & 0.886 \\
$\mathbf{1 4 - 2 1}$ & $609.44 \pm 6.56^{\mathrm{b}}$ & $616.92 \pm 5.75^{\mathrm{ab}}$ & $601.91 \pm 8.75^{\mathrm{b}}$ & $605.56 \pm 5.48^{\mathrm{b}}$ & $632.81 \pm 12.80^{\mathrm{a}}$ & 0.026 \\
$\mathbf{2 1 - 2 8}$ & $965.35 \pm 8.89$ & $953.78 \pm 8.80$ & $978.33 \pm 6.86$ & $954.44 \pm 4.97$ & $979.29 \pm 7.05$ & 0.120 \\
$\mathbf{2 8 - 3 5}$ & $1222.11 \pm 19.33^{\mathrm{b}}$ & $1218.00 \pm 13.55^{\mathrm{b}}$ & $1249.04 \pm 16.06^{\mathrm{ab}}$ & $1197.24 \pm 23.07^{\mathrm{b}}$ & $1280.09 \pm 14.23^{\mathrm{a}}$ & 0.031 \\
$\mathbf{3 5 - 4 2}$ & $1396.78 \pm 19.91$ & $1403.38 \pm 36.57$ & $1384.48 \pm 25.29$ & $1390.27 \pm 11.96$ & $1450.06 \pm 8.25$ & 0.295 \\
\hline $\mathbf{0 - 2 1}$ & $1103.09 \pm 10.64^{\mathrm{ab}}$ & $1112.89 \pm 10.72^{\mathrm{ab}}$ & $1062.58 \pm 10.18^{\mathrm{c}}$ & $1084.25 \pm 13.20^{\mathrm{bc}}$ & $1122.33 \pm 46^{\mathrm{a}}$ & 0.018 \\
$\mathbf{2 2 - 4 2}$ & $3601.84 \pm 49.53^{\mathrm{ab}}$ & $3520.69 \pm 22.06^{\mathrm{b}}$ & $3548.92 \pm 61.48^{\mathrm{b}}$ & $3541.95 \pm 37.06^{\mathrm{b}}$ & $3714.10 \pm 21.15^{\mathrm{a}}$ & 0.024 \\
$\mathbf{0 - 4 2}$ & $4704.93 \pm 54.52^{\mathrm{bc}}$ & $4659.29 \pm 20.55^{\mathrm{b}}$ & $4722.14 \pm 83.83^{\mathrm{bc}}$ & $4626.20 \pm 30.08^{\mathrm{b}}$ & $4835.13 \pm 26.97^{\mathrm{a}}$ & 0.044 \\
\hline
\end{tabular}

a,b,c: The differences between means in the same row with different letters are important, $\mathrm{P}<0.05$

Table 6. The effect of the capsicum oleoresin, carvacrol, cinnamaldehyde and their mixture added to the compound feed of broiler on feed conversion ratio, ((g feed/ $\left.\mathrm{g} B W G), \mathrm{x}^{ \pm} \mathrm{SEM}\right)$.

\begin{tabular}{lllllll}
\hline & \multicolumn{5}{c}{ Treatment Groups } \\
\cline { 2 - 6 } Day & Control & CAP & CAR & CIN & CAP + CAR + \\
\hline $\mathbf{0 - 7}$ & $1.66 \pm 0.06^{\mathrm{b}}$ & $1.43 \pm 0.02^{\mathrm{a}}$ & $1.36 \pm 0.02^{\mathrm{a}}$ & $1.43 \pm 0.06^{\mathrm{a}}$ & $1.33 \pm 0.06^{\mathrm{a}}$ & 0.001 \\
$\mathbf{7 - 1 4}$ & $1.07 \pm 0.01^{\mathrm{a}}$ & $1.15 \pm 0.01^{\mathrm{b}}$ & $1.09 \pm 0.01^{\mathrm{a}}$ & $1.13 \pm 0.02^{\mathrm{b}}$ & $1.13 \pm 0.00^{\mathrm{b}}$ & 0.000 \\
$\mathbf{1 4 - 2 1}$ & $1.24 \pm 0.00^{\mathrm{a}}$ & $1.29 \pm 0.01^{\mathrm{c}}$ & $1.28 \pm 0.01^{\mathrm{bc}}$ & $1.27 \pm 0.01^{\mathrm{abc}}$ & $1.25 \pm 0.01^{\mathrm{ab}}$ & 0.019 \\
$\mathbf{2 1 - 2 8}$ & $1.48 \pm 0.01^{\mathrm{a}}$ & $1.53 \pm 0.02^{\mathrm{b}}$ & $1.54 \pm 0.01^{\mathrm{b}}$ & $1.57 \pm 0.02^{\mathrm{b}}$ & $1.50 \pm 0.02^{\mathrm{ab}}$ & 0.044 \\
$\mathbf{2 8 - 3 5}$ & $1.72 \pm 0.06^{\mathrm{b}}$ & $1.61 \pm 0.04^{\mathrm{a}}$ & $1.74 \pm 0.03^{\mathrm{b}}$ & $1.64 \pm 0.02^{\mathrm{ab}}$ & $1.68 \pm 0.01^{\mathrm{ab}}$ & 0.002 \\
$\mathbf{3 5 - 4 2}$ & $2.05 \pm 0.09$ & $2.12 \pm 0.17$ & $2.15 \pm 0.11$ & $2.11 \pm 0.13$ & $1.93 \pm 0.04$ & 0.659 \\
\hline $\mathbf{0 - 2 1}$ & $1.32 \pm 0.02^{\mathrm{b}}$ & $1.28 \pm 0.01^{\mathrm{ab}}$ & $1.24 \pm 0.01^{\mathrm{a}}$ & $1.27 \pm 0.03^{\mathrm{ab}}$ & $1.24 \pm 0.02^{\mathrm{a}}$ & 0.018 \\
$\mathbf{2 2 - 4 2}$ & $1.74 \pm 0.02^{\mathrm{ab}}$ & $1.70 \pm 0.03^{\mathrm{a}}$ & $1.78 \pm 0.03^{\mathrm{b}}$ & $1.70 \pm 0.01^{\mathrm{a}}$ & $1.69 \pm 0.01^{\mathrm{a}}$ & 0.040 \\
$\mathbf{0 - 4 2}$ & $1.53 \pm 0.02^{\mathrm{b}}$ & $1.49 \pm 0.01^{\mathrm{ab}}$ & $1.51 \pm 0.02^{\mathrm{b}}$ & $1.50 \pm 0.01^{\mathrm{ab}}$ & $1.46 \pm 0.01^{\mathrm{a}}$ & 0.029 \\
\hline
\end{tabular}

a,b,c: The differences between means in the same row with different letters are important, $\mathrm{p}<0.05$

Considering Table 6, there was no significant difference among the groups in terms of feed conversion in the 35-42 $2^{\text {nd }}$ days ( $p>0.05$ ), while the difference was found significant in the $0-7$ th, 7-14th, 14-21st, 2128 th and $28-35^{\text {th }}$ days $(\mathrm{p}<0.05)$. Additionally, in the $0-7^{\text {th }}$ and $7-14^{\text {th }}$ days, feed conversion values for some experiment groups were found similar to that in the control group. The best feed conversion rate was found in the control group in both the $14-21^{\text {st }}$ and $21-28^{\text {th }}$ days, and in the CAP group in the $28-35^{\text {th }}$ days. According to the findings on feed conversion ratios based on periods, the values calculated for the periods of 0-21st, 22-42nd and 0-42nd day were significantly different among each other $(\mathrm{p}<0.05)$. The best feed conversion ratio was found in the CAP+CAR+CIN and CAR groups in the $0-21^{\text {st }}$ days, and in the CIN, CAP and CAP+CAR+CIN groups in the 22-42 ${ }^{\text {nd }}$ days. Additionally, the best feed conversion 
ratio in the $0-42^{\text {nd }}$ days was found in the CAP+CAR+CIN group. Results of relevant studies showed that addition of essential oils or bioactive substances to broiler chicken feed mixtures has varying effects. It was stated by Babaoglan (2008) that addition of $300 \mathrm{ppm}$ thymol/carvacrol in the $0-3^{\text {rd }}$ weeks, by AlMashdani et al. (2011b) that addition of $0.5 \%$ and $1 \%$ coriander oil, by Fotea et al. (2010) that addition of $1 \%$ carvacrol, and by Kucukyilmaz (2012) that addition of $48 \mathrm{mg} / \mathrm{kg}$ essential oil mixture increased the ratio of feed conversion; while it was reported by Shanoon et al. (2012) that addition of 10, 20 or 40 $\mathrm{mg} / \mathrm{kg} /$ day clove oil and by Akyurek and Yel (2011) that addition of $250 \mathrm{mg} / \mathrm{kg}$ thymol $+250 \mathrm{mg} / \mathrm{kg}$ carvacrol did not have an effect on feed conversion ratio. Alçiçek et al. (2004) reported that addition of essential oil mixture to the feed did not change feed conversion in a period of 0-21 days, but increased it in a period of 0-42 days. Based on the results obtained in the study, it is possible to say that addition of $\mathrm{CAP}, \mathrm{CAR}, \mathrm{CIN}$ or CAP+CAR+CIN increased the ratio of feed conversion in broiler chickens.

The effects of the trial on livability are given in Table 7. Along the trial (0-42), a total of 9 animals died including 1 in the control group, 1 in the CAP group, 2 in the CAR group, 4 in the CIN group, and 1 in the CAP+CAR+CIN group. Accordingly, it may be argued that the addition of $150 \mathrm{mg} / \mathrm{kg}$ capsicum oleoresin, carvacrol, cinnamaldehyde and their mixture (50 mg each) into the feed did not have negative effect on livability. It was seen that the results obtained from the study were in agreement with those of previous studies (Alcicek et al., 2004; Shanoon et al., 2012; Kucukyilmaz et al., 2012; Celikbilek et al., 2014).

Table 7. The effect of the capsicum oleoresin, carvacrol, cinnamaldehyde and their mixture added to the compound feed of broiler on livability, \% $(x \pm S E M)$.

\begin{tabular}{ll}
\hline Treatment Groups & Livability, \%** \\
\hline Control & 98.75 \\
CAP & 98.75 \\
CAR & 97.50 \\
CIN & 95 \\
CAP+CAR+CIN & 98.75 \\
$* \mathrm{P}$ & 0.265 \\
\hline
\end{tabular}

$* \mathrm{p}<0.05$

** Chi-square analysis was carried out,

\subsection{Carcass Characteristics}

Considering Table 8, the differences among the groups were statistically insignificant in terms of carcass characteristics $(\mathrm{P}>0.05)$ except carcass yield. The highest carcass yield was found in the CAP group, while the lowest was found in the CAR and control groups $(\mathrm{p}<0.05)$. The findings of the study were found to agree with those of Alcicek et al. (2004), Simsek et al. (2005), Shanoon et al. (2012), Duarte et al. (2013), Khattak et al. (2014) and Kirkpinar et al. (2014). Additionally Babaoglan and Kutlu (2008) reported that addition of thymol:carvacrol (1:1) did not affect the carcass yield, but reduced the abdominal fat ratio. According to Al-Kassie (2009), addition of $200 \mathrm{ppm}$ carvacrol reduced the abdominal fat ratio, while addition of 200 ppm cinnamon oil increased it. Awaad et al. (2014) reported that the addition of CAP+CAR+CIN to the feed reduced the abdominal fat by $0.27 \%$ in comparison to the control group. 
International Journal of Scientific and Technological Research

ISSN 2422-8702 (Online), DOI: 10.7176/JSTR/5-12-01

Vol.5, No.12, 2019

Table 8. The effect of the capsicum oleoresin, carvacrol, cinnamaldehyde and their mixture added to the compound feed of broiler on carcass characteristics, $(\mathrm{x} \pm \mathrm{SEM})$.

\begin{tabular}{|c|c|c|c|c|c|c|}
\hline \multirow[b]{2}{*}{ Characteristic } & \multicolumn{6}{|c|}{ Treatment Groups } \\
\hline & Control & CAP & CAR & CIN & $\mathrm{CAP}+\mathrm{CAR}+\mathrm{CIN}$ & $* \mathrm{P}$ \\
\hline $\begin{array}{l}\text { Slaughter weigh } \\
\text { (g) }\end{array}$ & t $2916.00 \pm 101.8$ & $2948.00 \pm 104.98$ & $2892.40 \pm 106.7$ & $2928.60 \pm 100.97$ & $3049.90 \pm 116.24$ & 0.857 \\
\hline $\begin{array}{l}\text { Carcass } \\
\text { weight }(\mathrm{g})\end{array}$ & $2167.50 \pm 83.34$ & $2228.10 \pm 79.78$ & $2121.00 \pm 78.78$ & $2182.50 \pm 75.66$ & $2271.30 \pm 88.15$ & 0.733 \\
\hline $\begin{array}{l}\text { Carcass yield } \\
(\%)\end{array}$ & $73.26 \pm 0.46^{\mathrm{b}}$ & $74.95 \pm 0.41^{\mathrm{a}}$ & $73.33 \pm 0.43^{\mathrm{b}}$ & $74.54 \pm 0.46^{\mathrm{ab}}$ & $74.46 \pm 0.36^{\mathrm{ab}}$ & 0.027 \\
\hline Breast, (g) & $789.40 \pm 40.06$ & $789.70 \pm 32.42$ & $748.50 \pm 21.63$ & $805.20 \pm 27.77$ & $813.80 \pm 30.93$ & 0.631 \\
\hline Breast, $(\%)^{* *}$ & $26.98 \pm 0.62$ & $26.88 \pm 0.77$ & $25.96 \pm 0.39$ & $27.54 \pm 0.52$ & $26.71 \pm 0.37$ & 0.340 \\
\hline Leg, (g) & $546.10 \pm 28.06$ & $544.20 \pm 30.81$ & $540.20 \pm 27.93$ & $548.30 \pm 23.93$ & $577.00 \pm 30.46$ & 0.895 \\
\hline Leg, $(\%)^{* *}$ & $18.67 \pm 0.47$ & $18.37 \pm 0.54$ & $18.63 \pm 0.51$ & $18.69 \pm 0.30$ & $18.86 \pm 0.44$ & 0.964 \\
\hline $\begin{array}{l}\text { Abdominal } \\
\text { fat, (g) }\end{array}$ & $22.00 \pm 2.51$ & $22.38 \pm 2.69$ & $15.10 \pm 2.88$ & $19.00 \pm 2.53$ & $20.30 \pm 3.30$ & 0.377 \\
\hline $\begin{array}{l}\text { Abdominal } \\
\text { fat, }(\%)^{* *}\end{array}$ & $0.79 \pm 0.11$ & $0.63 \pm 0.14$ & $0.54 \pm 0.11$ & $0.67 \pm 0.10$ & $0.70 \pm 0.13$ & 0.676 \\
\hline
\end{tabular}

a,b: The differences between means in the same row with different letters are important, $* \mathrm{p}<0.05$

** The body weights have been used for calculation of the proportional weights.

Table 9. The effect of the capsicum oleoresin, carvacrol, cinnamaldehyde and their mixture added to the compound feed of broiler on some circulation and secretory organ weights, $(x \pm S E M)$.

\section{Treatment Groups}

\begin{tabular}{|c|c|c|c|c|c|c|}
\hline \multirow[b]{2}{*}{ Characteristic } & \multirow[b]{2}{*}{ Control } & \multirow[b]{2}{*}{ CAP } & \multirow[b]{2}{*}{ CAR } & \multirow[b]{2}{*}{ CIN } & \\
\hline & & & & & $\begin{array}{l}\text { CAP + CAR + } \\
\text { CIN }\end{array}$ & $\mathrm{P}$ \\
\hline Liver, (g) & $49.80 \pm 2.73$ & $48.90 \pm 2.28$ & $50.00 \pm 3.38$ & $52.40 \pm 2.65$ & $47.40 \pm 2.74$ & 0.785 \\
\hline Liver, $(\%)^{* *}$ & $1.70 \pm 0.05$ & $1.67 \pm 0.07$ & $1.73 \pm 0.09$ & $1.79 \pm 0.08$ & $1.55 \pm 0.06$ & 0.181 \\
\hline Heart, (g) & $13.40 \pm 1.11$ & $13.10 \pm 1.04$ & $13.50 \pm 0.79$ & $12.90 \pm 1.20$ & $13.10 \pm 1.00$ & 0.994 \\
\hline Heart, $(\%)^{* *}$ & $0.46 \pm 0.03$ & $0.44 \pm 0.02$ & $0.47 \pm 0.02$ & $0.44 \pm 0.03$ & $0.43 \pm 0.02$ & 0.821 \\
\hline Spleen, (g) & $3.35 \pm 0.35$ & $3.14 \pm 0.37$ & $2.84 \pm 0.28$ & $2.73 \pm 0.21$ & $2.33 \pm 0.15$ & 0.114 \\
\hline Spleen, $(\%)^{* *}$ & $0.11 \pm 0.01$ & $0.11 \pm 0.01$ & $0.10 \pm 0.01$ & $0.10 \pm 0.01$ & $0.08 \pm 0.01$ & 0.024 \\
\hline Pancreas, (g) & $6.11 \pm 0.39$ & $5.48 \pm 0.27$ & $5.07 \pm 0.41$ & $5.39 \pm 0.36$ & $5.83 \pm 0.41$ & 0.343 \\
\hline Pancreas, $(\%)^{* *}$ & $0.21 \pm 0.02$ & $0.19 \pm 0.01$ & $0.18 \pm 0.01$ & $0.18 \pm 0.01$ & $0.19 \pm 0.01$ & 0.361 \\
\hline $\begin{array}{l}\text { Bursa Fabricius, } \\
\text { (g) }\end{array}$ & $4.82 \pm 0.39$ & $4.49 \pm 0.39$ & $3.86 \pm 0.35$ & $4.86 \pm 0.50$ & $5.38 \pm 0.61$ & 0.236 \\
\hline $\begin{array}{l}\text { Bursa Fabricius, } \\
(\%)^{* *}\end{array}$ & $0.16 \pm 0.01$ & $0.15 \pm 0.01$ & $0.14 \pm 0.01$ & $0.17 \pm 0.02$ & $0.18 \pm 0.02$ & 0.448 \\
\hline
\end{tabular}

Considering Table 9, the difference among the groups in terms of the circulation and secretion organs obtained from the slaughtered animals and the ratios of these in total live weight was not significant ( $>>0.05)$. Langhout (2000) stated that essential oils stimulate digestive system, increase pancreatic enzymes and improve liver functions in poultry. Yildiz (2007) found that $1-2 \mathrm{~kg} /$ ton carvacrol + thymol + rosmarinic acid combination did not have effects on the weights of bursa, liver and pancreas, and the spleen weight decreased by the increased dosage. Al-Kassie (2009) reported that an addition of 100-200 ppm thyme or cinnamon extract increased liver weight in line with dosage, heart weight decreased by $100 \mathrm{ppm}$ addition of both extracts, while it increased by $200 \mathrm{ppm}$ addition. Shanoon et al. (2012) stated that addition of $20-40 \mathrm{mg} / \mathrm{kg}$ ginger oil did not have an effect on heart and pancreas

11 | P a g e www.iiste.org 
weights, but liver weight increased in line with the dosage. According to the results of this study, it was observed that the addition of CAP, CAR, CIN or CAP+CAR+CIN had varying effects on the organs of broiler chickens.

Considering Table 10, the difference among the groups in terms of glandular stomach and proportional glandular stomach weights, gizzard and proportional gizzard weights, total intestine and proportional intestine weights was statistically significant $(\mathrm{p}<0.05)$. While the lowest glandular stomach and proportional glandular stomach weights were found in the CIN group, there was no statistically significant difference among other experiment groups. The highest gizzard weight was in CIN and $\mathrm{CAP}+\mathrm{CAR}+\mathrm{CIN}$, the highest proportional gizzard weight was in CIN, and the highest total intestine and proportional total intestine was found in the control group. When the groups were analyzed in terms of weights regarding the sections of the intestines (duodenum, jejunum and ileum) their proportions, the difference among the means was found statistically significant $(\mathrm{p}<0.05)$. The highest duodenum weight and proportion, jejunum proportion and ileum weight were observed in the control group $(\mathrm{p}<0.05)$. Additionally, the highest jejunum weigh was found in control and CAR, and the highest ileum proportion was found in control and CAP $(p<0.05)$. When the groups' large intestine and proportional large intestine weights were analyzed, it was seen that the differences for both parameters were statistically significant $(\mathrm{p}<0.05)$. Both large intestine weight and large intestine proportion were found the highest in the control group. Accordingly, it may be stated that addition of CAP, CAR, CIN and CAP+CAR+CIN into the feed mixture had a reducing effect on the weights of digestion organs ( $p<0.05)$. Nafaji and Torki $(2010)$ found that addition of $200 \mathrm{mg} / \mathrm{kg}$ thyme, cinnamon and clove oil did not have an effect on the weights of duodenum, jejunum and ileum, while according to Kucukyilmaz (2012), a commercial mixture of essential oils did not have an effect on small and large intestines. Thus, it was seen that the results obtained in this study were different to those in previous studies.

Table 10. The effect of the capsicum oleoresin, carvacrol, cinnamaldehyde and their mixture added to the compound feed of broiler on digestive organ weights, $(x \pm S E M)$.

\begin{tabular}{|c|c|c|c|c|c|c|}
\hline \multirow[b]{2}{*}{ Characteristic } & \multicolumn{5}{|c|}{ Treatment Groups } & \multirow[b]{2}{*}{$* \mathrm{P}$} \\
\hline & Control & CAP & CAR & CIN & $\begin{array}{l}\text { CAP + CAR } \\
+ \text { CIN }\end{array}$ & \\
\hline $\begin{array}{l}\text { Grandular } \\
\text { stomach, (g) }\end{array}$ & $9.50 \pm 1.46^{\mathrm{a}}$ & $8.40 \pm 0.48^{\mathrm{a}}$ & $9.30 \pm 1.04^{\mathrm{a}}$ & $5.39 \pm 0.36^{\mathrm{b}}$ & $9.00 \pm 0.63^{\mathrm{a}}$ & 0.013 \\
\hline $\begin{array}{l}\text { Grandular } \\
\text { stomach, }(\%)^{* *}\end{array}$ & $0.32 \pm 0.04^{\mathrm{a}}$ & $0.29 \pm 0.01^{\mathrm{a}}$ & $0.32 \pm 0.03^{\mathrm{a}}$ & $0.18 \pm 0.01^{\mathrm{b}}$ & $0.30 \pm 0.02^{\mathrm{a}}$ & 0.003 \\
\hline Gizzard, (g) & $29.40 \pm 2.27^{\mathrm{ab}}$ & $26.70 \pm 2.03^{\mathrm{ab}}$ & $23.60 \pm 1.35^{\mathrm{b}}$ & $31.80 \pm 2.02^{\mathrm{a}}$ & $31.20 \pm 2.16^{\mathrm{a}}$ & 0.032 \\
\hline Gizzard, $(\%)^{* *}$ & $1.36 \pm 0.10^{\mathrm{ab}}$ & $1.21 \pm 0.10^{\mathrm{b}}$ & $1.11 \pm 0.05^{\mathrm{b}}$ & $1.52 \pm 0.09^{\mathrm{a}}$ & $1.38 \pm 0.10^{\mathrm{ab}}$ & 0.030 \\
\hline $\begin{array}{l}\text { Total intestine, } \\
\text { (g) }\end{array}$ & $76.50 \pm 3.16^{\mathrm{a}}$ & $66.20 \pm 2.32^{\mathrm{b}}$ & $70.70 \pm 3.82^{\mathrm{ab}}$ & $68.22 \pm 3.90^{\mathrm{ab}}$ & $61.30 \pm 2.70^{\mathrm{b}}$ & 0.021 \\
\hline $\begin{array}{l}\text { Total intestine, } \\
(\%)^{* *}\end{array}$ & $2.65 \pm 0.13^{\mathrm{a}}$ & $2.25 \pm 0.03^{\mathrm{bc}}$ & $2.44 \pm 0.08^{\mathrm{ab}}$ & $2.49 \pm 0.18^{\mathrm{ab}}$ & $2.01 \pm 0.06^{\mathrm{c}}$ & 0.003 \\
\hline Duodenum, (g) & $12.50 \pm 0.70^{\mathrm{a}}$ & $9.60 \pm 0.83^{b}$ & $9.30 \pm 0.87^{b}$ & $9.00 \pm 5.00^{\mathrm{b}}$ & $9.70 \pm 0.68^{\mathrm{b}}$ & 0.010 \\
\hline $\begin{array}{l}\text { Duodenum, } \\
(\%) * *\end{array}$ & $0.43 \pm 0.03^{\mathrm{a}}$ & $0.32 \pm 0.02^{\mathrm{b}}$ & $0.32 \pm 0.03^{\mathrm{b}}$ & $0.36 \pm 0.03^{\mathrm{ab}}$ & $0.32 \pm 0.02^{\mathrm{b}}$ & 0.013 \\
\hline Jejenum, $(\mathrm{g})$ & $38.20 \pm 1.62^{\mathrm{a}}$ & $33.40 \pm 1.54^{\mathrm{ab}}$ & $38.25 \pm 1.68^{\mathrm{a}}$ & $35.44 \pm 2.31^{\mathrm{ab}}$ & $30.38 \pm 1.93^{\mathrm{b}}$ & 0.021 \\
\hline Jejenum, $(\%)^{* *}$ & $1.32 \pm 0.07^{\mathrm{a}}$ & $1.15 \pm 0.07^{\mathrm{ab}}$ & $1.30 \pm 0.06^{\mathrm{a}}$ & $1.18 \pm 0.08^{\mathrm{ab}}$ & $1.00 \pm 0.05^{\mathrm{b}}$ & 0.023 \\
\hline İleum, (g) & $8.92 \pm 0.57^{\mathrm{a}}$ & $7.00 \pm 0.62^{\mathrm{b}}$ & $6.40 \pm 0.65^{\mathrm{b}}$ & $8.00 \pm 0.50^{\mathrm{ab}}$ & $7.30 \pm 0.54^{\mathrm{ab}}$ & 0.038 \\
\hline İleum, $(\%)^{* *}$ & $0.41 \pm 0.02^{\mathrm{a}}$ & $0.42 \pm 0.04^{\mathrm{a}}$ & $0.30 \pm 0.03^{b}$ & $0.37 \pm 0.03^{\mathrm{ab}}$ & $0.33 \pm 0.03^{\mathrm{ab}}$ & 0.043 \\
\hline $\begin{array}{l}\text { Large intestine, } \\
(\mathrm{g})\end{array}$ & $18.29 \pm 0.97^{\mathrm{a}}$ & $14.80 \pm 0.77^{\mathrm{bc}}$ & $17.12 \pm 0.91^{\mathrm{ab}}$ & $16.57 \pm 0.92^{\mathrm{ab}}$ & ${ }^{c} 14.00 \pm 0.86^{c}$ & 0.009 \\
\hline $\begin{array}{l}\text { Large intestine, } \\
(\%)^{* *}\end{array}$ & $0.91 \pm 0.08^{a}$ & $0.67 \pm 0.04^{\mathrm{b}}$ & $0.75 \pm 0.03^{b}$ & $0.71 \pm 0.06^{\mathrm{b}}$ & $0.62 \pm 0.04^{b}$ & 0.003 \\
\hline
\end{tabular}




\subsection{Intestinal Microflora}

On the $42^{\text {nd }}$ day of the trial, Lactobacillus spp., Staphylococcus aureus, Clostridium perfringens counts and Salmonella spp. (positive/negative) test were performed on the ileum part of the intestines of the animals taken for each group and the results are given in Table 11. When Table 11 is examined, Salmonella spp. was isolated in 5 out of 5 samples taken for the control group and only 1 out of each group in the samples taken for the treatments groups. It was determined that the addition of capsicum oleoresin, carvacrol, cinnamaldehyde and their combinations to the mixed feeds did not affect the number of Staphylococcus aureus, Clostridium perfringens ( $>0.05$ ), while it affected the Lactobacillus spp. count in a significant level $(\mathrm{p}<0.05)$. When the groups were evaluated in terms of Staphylococcus aureus, Clostridium perfringens numbers, the both microorganisms were found to be at uncountably low levels in all groups. When the average values for the ileum Lactobacillus spp. counts were evaluated, it was detected that the ileums of the treatment group animals fed with CAP+CAR+CIN added feeds contained a significantly higher amount of Lactobacillus spp. content $(\mathrm{P}<0.05)$ with an average value of $4.48\left(\log _{10}\right)$ CFU/g compared to the ileums of the control, CIN, CAP and CAR group animals with average values of 3.74, 3.56, 3.25 and $3.24\left(\log _{10}\right)$ CFU/g respectively. The control, CIN, CAP and CAR groups on the other hand were similar in nature and there was no statistically significant difference between them ( $>0.05$ ). At the end of the trial, the intestines of the animals were removed, microbiological analyzes were conducted in the ileum part and while there was a significant difference in Lactobacillus spp. counts between the groups $\mathrm{p}<0.05$ ), no significant difference was observed in Staphylococcus aureus, Clostridium perfringens numbers ( $\mathrm{p}>0.05$ ) (see Table 11). When the results obtained in this study are compared to the results of the studies where other herbal extracts and bioactive components that affect intestinal microflora of broilers were used; while they show similarity with the results indicating that the thymol:carvacrol (1:1) mix added to broiler feeds by $200 \mathrm{mg} / \mathrm{kg}$ increased Lactobacillus spp. and Bifidobacterium numbers (Hashemipour et al., 2013), they differ from the results of another study conducted by Sharifi et al. (2013) where it was shown that the addition of 4 different aromatic plants in dried form (cumin, mint, yarrow and poley-haired herba chamaedrys) to the mix broiler (Arbor Acres) feeds by $15,3,2$ and $2 \mathrm{~g} / \mathrm{kg}$ respectively significantly reduced the Clostridium (log 10/g) numbers in the groups except for the cumin group, and did not change Lactobacillus numbers in all the treatments groups. Shanoon et al. (2012) reported that the addition of ginger oil to the mix feed of broilers (Ross 308) consisting of male and female groups with different doses $(0,10,20,40 \mathrm{mg} / \mathrm{kg} / \mathrm{day})$ significantly reduced Escherichia coli, Enterobacteria, Staphylococci, Salmonella and Shigella spp. numbers; Zhou et al. (2007) reported that the combination of cinnamladehyde $(100 \mathrm{mg} / \mathrm{l})+$ carvacrol $(200 \mathrm{mg} / \mathrm{l})$ significantly reduced decreased the development of Salmonella typhimurium in bacteria culture (Mueller Hinton); Xu et al. (2008) reported that depending on the increasing doses $(0,100,200,400,800 \mathrm{mg} / \mathrm{l})$, the addition of carvacrol:thymol (1-1) combinations to Escherichia coli bacteria culture (Mueller Hinton broth, $\left.1^{\times} 107 \mathrm{CFU} / \mathrm{ml}\right)$ significantly reduced the development of E.coli; Yossa et al. (2012) treated E.coli (0157:H7) and Salmonella spp. bacteria cultures (Luria-Bertani broth, $1^{\times} 107 \mathrm{CFU} / \mathrm{ml}$ ) with cinnamaldehyde in two different doses (800 ve $1000 \mathrm{ppm}$ ) and at the end of 1 hour incubation they reported that bacteria populations were decreased to an unidentifiably low degree in both doses.

Table 11. Effects of capsicum oleoresin, carvacrol, cinnemaldehyde and mixtures added to broiler mixed feeds on intestinal microflora $\left(\log _{10}\right) \mathrm{CFU} / \mathrm{g},(\mathrm{x} \pm \mathrm{SEM})$.

\section{*Treatment groups}

\begin{tabular}{|c|c|c|c|c|c|c|}
\hline Microorganism & Control & CAP & CAR & CIN & $\begin{array}{c}\text { CAP+CAR+ } \\
\text { CIN }\end{array}$ & $\mathbf{P}$ \\
\hline Lactobacillus spp. & $3.74 \pm 0.38^{\mathrm{b}}$ & $3.25 \pm 0.18^{\mathrm{b}}$ & $3.24 \pm 0.07^{\mathrm{b}}$ & $3.56 \pm 0.20^{\mathrm{b}}$ & $4.48 \pm 0.18^{\mathrm{a}}$ & 0.021 \\
\hline S. aureus & $<10$ & $<10$ & $<10$ & $<10$ & $<10$ & - \\
\hline C. perfringens & $<10$ & $<10$ & $<10$ & $<10$ & $<10$ & - \\
\hline Salmonella spp. & Positive & Negative & Negative & Negative & Negative & - \\
\hline
\end{tabular}

a,b,c: Means within rows with different superscript differ at $\mathrm{p}<0,05, *$ Control: no feed additive, CAP: $150 \mathrm{mg} / \mathrm{kg}$ capsicum oleoresin, CAR: $150 \mathrm{mg} / \mathrm{kg}$ carvacrol, CIN: $150 \mathrm{mg} / \mathrm{kg}$ cinnamaldehyde and CAP+CAR+CIN: $150 \mathrm{mg} / \mathrm{kg}$ mixture (50 mg each, capsicum oleoresin + carvacrol + cinnamaldehyde). 


\subsection{Some Blood Parameters}

Findings of some biochemical parameters detected in blood samples taken from brachial veins of animals before slaughter to be laid open for carcass features on day 42 of trial are given in Table 12. When Table 12 was examined, it was determined that bioactive secondary plant metabolite addition insignificantly ( $p>0.05$ ) affected glucose, ALT, total cholesterol and HDL values, cinnamaldehyde and mixture group decreased AST values, carvacrol cinnamaldehyde and capsicum oleoresin group decreased triglyceride value, carvacrol and mixture group decreased LDL values and cinnamaldehyde group increased albumin and total protein levels significantly $(\mathrm{p}<0.05)$. Among examined biochemical parameters, AST 337-500 U/L, ALT 5.33-6.89 U/L, glucose 232.22-241.33 mg/dl, triglyceride 31.11-60.44 mg/dl, total cholesterol $106.70-118.33 \mathrm{mg} / \mathrm{dl}$, HDL $94.80-99.22 \mathrm{mg} / \mathrm{dl}$, LDL $3.76-7.85 \mathrm{mg} / \mathrm{kg}$, total protein $3.01-3.52 \mathrm{mg} / \mathrm{dl}$ and albumin 1.52-1.65 mg/dl has exhibited change from mean values. When biochemical analysis result belonging to blood parameters such as glucose, ALT, total cholesterol and HDL, it was determined that differences among treatment groups were not statistically significant $p>0.05$ ). When treatment groups were compared to control group, it is seen that cinnamaldehyde and mixture group has decreased AST values while carvacrol group has increased it, carvacrol, cinnamaldehyde and capsicum oleoresin group has decreased triglyceride value, carvacrol and mixture group has decreased LDL values and cinnamaldehyde group has increased albumin and total protein levels significantly $(\mathrm{p}<0.05)$ (see Table 12). Calislar et al. (2009) revealed that addition of oregano essential oil (81.89\% carvacrol, 5.1\% xterpinene, $3.76 \%$ cymen, $2.42 \%$ thymol) at levels of 300, 500 and $700 \mathrm{ppm}$ to broiler mixed feeds did not affect total cholesterol, HDL and triglyceride levels. Similarly, in a study made in 2004, Lee et al. added carvacrol and cinnamaldehyde and mixtures thereof (carvacrol and cinnamaldehyde of $100 \mathrm{ppm}$ each) in $200 \mathrm{ppm}$ levels to the mixed feeds of female broiler feeding on feeds containing carboxymethyl cellulose, and as a result they stated that treatment group as compared to control group did not affect plasma lipid levels (total cholesterol, HDL, triglyceride and phospholipid). Najafi and Torki (2010) revealed that addition of thyme, cinnamon and clove essential oil in $200 \mathrm{ppm}$ levels to broiler mixed feeds did not affect total cholesterol, triglyceride and HDL values, difference between the highest and the lowest hematocrit (HCT) and red blood cell (RBC) values were seen in groups fed with cinnamon and clove essential oils, however they revealed that difference relating to this values in groups fed with thyme essential oil and control group were not present.

Table 12. Effects of capsicum oleoresin, carvacrol, cinnemaldehyde and mixtures supplementation to broiler mixed feeds on some blood parameters $(\mathrm{x} \pm \mathrm{SEM})$.

\begin{tabular}{ccccccc}
\hline \multirow{2}{*}{$\begin{array}{c}\text { BLOOD } \\
\text { PARA- } \\
\text { METERS }\end{array}$} & Control & CAP & CAR & CIN & $\begin{array}{c}\text { CAP+CAR+CI } \\
\text { N }\end{array}$ & P \\
\cline { 2 - 6 } \cline { 3 - 5 } & & & & & \\
\hline $\begin{array}{c}\text { Glucose } \\
(\mathrm{mg} / \mathrm{dl})\end{array}$ & $232.22 \pm 4.26$ & $235.78 \pm 5.56$ & $237.00 \pm 3.77$ & $241.33 \pm 6.13$ & $239.56 \pm 4$ & 0.716 \\
\hline AST (U/L) & $428.60 \pm 6.35^{\mathrm{b}}$ & $500.00 \pm 33.1^{\mathrm{c}}$ & $444.50 \pm 8.2^{\mathrm{bc}}$ & $367.29 \pm 16.2^{\mathrm{a}}$ & $337.00 \pm 41^{\mathrm{a}}$ & 0.000 \\
\hline ALT (U/L) & $5.33 \pm 0.44$ & $6.56 \pm 0.87$ & $6.60 \pm 0.65$ & $6.33 \pm 0.62$ & $6.89 \pm 1.06$ & 0.655 \\
\hline $\begin{array}{c}\text { Triglyceride } \\
(\mathrm{mg} / \mathrm{dl})\end{array}$ & $35.67 \pm 5.6^{\mathrm{a}}$ & $40.00 \pm 4.77^{\mathrm{ab}}$ & $42.20 \pm 7.65^{\mathrm{ab}}$ & $60.44 \pm 9.49^{\mathrm{b}}$ & $31.11 \pm 5.3^{\mathrm{a}}$ & 0.009 \\
\hline $\begin{array}{c}\text { Total } \\
\text { Cholesterol } \\
(\mathrm{mg} / \mathrm{dl})\end{array}$ & $108.89 \pm 3.47$ & $115.44 \pm 6.35$ & $106.70 \pm 2.57$ & $118.33 \pm 8.56$ & $109.89 \pm 3.2$ & 0.494 \\
\hline $\begin{array}{c}\text { HDL } \\
(\mathrm{mg} / \mathrm{dl})\end{array}$ & $97.11 \pm 2.43$ & $98.33 \pm 5.16$ & $94.80 \pm 2.69$ & $98.67 \pm 3.13$ & $99.22 \pm 2.66$ & 0.884 \\
\hline $\begin{array}{c}\text { LDL } \\
(\mathrm{mg} / \mathrm{dl})\end{array}$ & $7.85 \pm 1.35^{\mathrm{b}}$ & $5.4 \pm 0.31^{\mathrm{ab}}$ & $3.76 \pm 0.43^{\mathrm{b}}$ & $5.48 \pm 0.69^{\mathrm{ab}}$ & $4.96 \pm 0.75^{\mathrm{a}}$ & 0.000 \\
\hline $\begin{array}{c}\text { Total } \\
\text { Protein } \\
(\mathrm{mg} / \mathrm{dl})\end{array}$ & $3.17 \pm 0.08^{\mathrm{b}}$ & $3.20 \pm 0.05^{\mathrm{b}}$ & $3.16 \pm 0.10^{\mathrm{b}}$ & $3.52 \pm 0.18^{\mathrm{a}}$ & $3.01 \pm 0.05^{\mathrm{b}}$ & 0.021 \\
\hline $\begin{array}{c}\text { Albumin } \\
(\mathrm{mg} / \mathrm{dl})\end{array}$ & $1.61 \pm 0.03^{\mathrm{abc}}$ & $1.63 \pm 0.03^{\mathrm{ab}}$ & $1.52 \pm 0.03^{\mathrm{c}}$ & $1.65 \pm 0.05^{\mathrm{a}}$ & $1.53 \pm 0.03^{\mathrm{bc}}$ & 0.025 \\
\hline
\end{tabular}


a,b,c: Means within rows with different superscript differ at $\mathrm{p}<0,05$, ${ }^{*}$ Control: no feed additive, CAP: $150 \mathrm{mg} / \mathrm{kg}$ capsicum oleoresin, CAR: $150 \mathrm{mg} / \mathrm{kg}$ carvacrol, CIN: $150 \mathrm{mg} / \mathrm{kg}$ cinnamaldehyde and $\mathrm{CAP}+\mathrm{CAR}+\mathrm{CIN}: 150 \mathrm{mg} / \mathrm{kg}$ mixture (50 mg each, capsicum oleoresin + carvacrol + cinnamaldehyde).

\subsection{IGF1 Gene Expression Levels}

Considering the Table 13, in animals fed with feeds containing $150 \mathrm{mg} / \mathrm{kg}$ capsicum oleoresin, carvacrol, cinnamaldehyde or the mixture of these in equal proportions, the differences among groups in terms of IGF1 expression were insignificant ( $\mathrm{p}>0.05) . \mathrm{C}_{\mathrm{T}}, \Delta \mathrm{C}_{\mathrm{T}}, \Delta \Delta \mathrm{C}_{\mathrm{T}}$ and fold-change values of GADPH and IGF1 genes are presented in Table 13. Comparison of control, CAP, CAR, CIN and CAP+CAR+CIN groups in terms of mean $\mathrm{C}_{\mathrm{T}}$ and mean $\Delta \mathrm{C}_{\mathrm{T}}$ values of GAPDH and IGF1 genes did not show any statistically significant difference between the groups $(\mathrm{p}>0.05)$. Whether treatment caused any increase or decrease in IGF1 expression was determined by calculation of its fold-change. Accordingly, in comparison to the control group, IGF1 gene expression was increased by 18 folds in CAP group, 8.88 folds in CAR group, 38.05 folds in CAP+CAR+CIN group, where as it was unchanged in the CIN group. There are no studies in the literature similar to these findings, while Kita et al. (1996) reported that the broilers fed with low-protein rations did not show different IGF1 gene expression in liver tissue in comparison to the control group. Kim et al. (2010), as a result of their study investigating the expression levels of genes on the intestinal tissue with addition of CAR $(5 \mathrm{mg} / \mathrm{kg})$, CIN $(3 \mathrm{mg} / \mathrm{kg})$ and CAP (2 $\mathrm{mg} / \mathrm{kg}$ ) into feed mixtures of broiler chickens, observed that 26 genes increased and 48 genes decreased among 72 in the group with CAR addition, 31 increased and 31 decreased among 62 in the group with CIN addition; while in the group with the highest amount of changes, the group with CAP addition, 156 genes increased and 98 genes decreased. As there are no studies in the literature regarding the effects of CAP, CAR, CIN addition on IGF1 gene expression, this study discussed other studies about IGF1 gene expression. While Heck et al. (2003) found that the IGF1 expression in the ovaries of broiler breeding chicken fed as ad libitum and with restriction did not change with age, Guernec et al. (2004) observed that the IGF1 mRNA levels in the Pectoralis major (PM) and Sartorius (SART) muscles of broilers that were left hungry between 0 and 2 days ( $48 \mathrm{~h}$ hungry, $48 \mathrm{~h}$ free) at 4 weeks of age for 16, 24 and 48 hours and fed freely for 16, 24 and 48 hours, increased in comparison to the group left hungry in the freefeeding group.

Table 13. $\mathrm{C}_{\mathrm{T}}, \Delta \mathrm{C}_{\mathrm{T}}, \Delta \Delta \mathrm{C}_{\mathrm{T}}$ and fold-change values of GADPH and IGF1 genes in control and treatment Groups.

\begin{tabular}{|c|c|c|c|c|c|c|}
\hline \multirow[b]{2}{*}{ Genes } & \multicolumn{5}{|c|}{ Treatment Groups } & \multirow[b]{2}{*}{$* \mathrm{P}$} \\
\hline & Control & CAP & CAR & $\mathrm{CIN}$ & $\mathrm{CAP}+\mathrm{CAR}+\mathrm{CIN}$ & \\
\hline $\begin{array}{c}\text { GADPH } \\
\text { Average } C_{T}\end{array}$ & $14.91 \pm 0.58$ & $14.99 \pm 0.37$ & $14.69 \pm 0.42$ & $14.41 \pm 0.32$ & $14.91 \pm 0.16$ & 0.832 \\
\hline $\begin{array}{c}\text { IGF1 } \\
\text { Average } \mathrm{C}_{\mathrm{T}}\end{array}$ & $34.20 \pm 2.22$ & $30.43 \pm 0.27$ & $30.83 \pm 1.06$ & $33.62 \pm 1.79$ & $29.49 \pm 0.64$ & 0.194 \\
\hline $\begin{array}{c}\Delta \mathrm{C}_{\mathrm{T}} \\
\text { IGF1-GAPDH }\end{array}$ & $19.49 \pm 2.10$ & $14.58 \pm 0.27$ & $16.79 \pm 1.59$ & $19.25 \pm 2.07$ & $14.62 \pm 0.45$ & 0.189 \\
\hline $\begin{array}{c}* * \Delta \Delta \mathrm{C}_{\mathrm{T}} \\
\Delta \mathrm{C}_{\mathrm{T}}-\Delta \mathrm{C}_{\mathrm{T}} \text {, Control }\end{array}$ & 0.00 & -4.71 & -3.15 & -0.07 & -5.25 & - \\
\hline $\begin{array}{l}\text { IGF1 Fold } \\
\text { Expression }\end{array}$ & 1.00 & 18.00 & 8.88 & 1.05 & 38.05 & - \\
\hline
\end{tabular}

their mean values are presented.

\section{CONCLUSION}

In conclusion, based on the findings of the present study, individual positive and/or negative effects of capsicum oleoresin, carvacrol, cinnamaldehyde and their mixture addition to the mixed feeds of broiler chickens on the investigated characteristics and criteria have been observed, and it was thought that these negative effects might be caused by the high level of bioactive substance doses used. However, it was detected that the addition of mixture $(50 \mathrm{mg} / \mathrm{kg}$ capsicum oleoresin $+50 \mathrm{mg} / \mathrm{kg}$ carvacrol $+50 \mathrm{mg} / \mathrm{kg}$ cinnamaldehyde) to the mixed feeds of broiler chickens improved the performance, carcass yield, some 
organ weights, intestinal microflora and some blood parameters in broiler chickens. And it can be concluded that these bioactive secondary plant metabolites can be used in feeding of broilers as natural feed additive. Especially as this mixture created positive effects on broiler performance, it can be recommended for use in practice. Moreover, determination of levels of use of combination of this bioactive materials with different doses, research of effects thereof on amount and quality of animal products, improvement of practical application and repetition with mixed feed having different structure in feeding applications.

\section{Acknowledgements}

Not applicable.

\section{Funding}

This article has been prepared from the master's thesis of Hasan Huseyin IPCAK supported by TUBITAK "2210-C Domestic Graduate Scholarship Programme for Priority Areas" and EGETAV company in Izmir/Turkey. He is also thankful to TUBITAK for financial support during my thesis period. Besides, the authors gratefully acknowledge financial support from Faculty Member Training Program (ÖYP).

\section{Availability of data and materials}

Authors approved the data and materials availability.

\section{Ethics approval}

All experimental procedurs involving animals were conducted in accordance with the Animal Experimental Guidelines provided by the Ege University Ethical Committee (No: 2014-013).

\section{Conflict of interest statement}

Authors declare no conflict of interest.

\section{References}

ABI PRISM 7700 User Bulletin No. 2. Sequence Detection System, Revision A, pp. 11-13, 1997 (updated 10/2001).

Akyurek H. and Yel A., 2011, Influence of dietary thymol and carvacrol preparation and/or an organic acid blend on growth performance, digestive organs and intestinal microbiota of broiler chickens, African Journal of Microbiology Research, vol. 5(7).

Alcicek, A., Bozkurt, M. and Cabuk, M., 2003. The effect of an essential oil combination derived from selected herbs growing wild in Turkey on broiler performance. South African Journal of Animal Science, 2003, 33 (2).

Alcicek A., Bozkurt M. and Cabuk M., 2004, The effect of a mixture of herbal essential oils, an organic acid or a probiotic on broiler performance. South African Journal of Animal Science, 34 (4) $217-222$.

Al-Kassie G.A.M., 2009, Influence of two plant extracts derived from thyme and cinnamon on broiler performance, Pakistan Vet. J., 29(4): 169-173.

Al-Mashhadani E.H., Al-Jaff F.K., Farhan Y.M. and AL-Mashhadani H.E., 2011a. Effect of anise, thyme essential oils and their mixture (eom) on broiler performance and some physiological traits. Egypt. Poult. Sci. Vol, (31) (II): 481-489. 
Al-Mashhadani E.H., Al-Jaff F.K., Hamodi S.J. and Al-Mashhadani H.E., 2011b. Effect of different levels of coriander oil on broiler performance and some physiological traits under summer condition, Pakistan Journal of Nutrition, 10 (1): 10-14.

Awaad M.H.H., Elmenawey M. and Ahmed K. A., 2014, Effect of a specific combination of carvacrol, cinnamaldehyde, and capsicum oleoresin on the growth performance, carcass quality and gut integrity of broiler chickens. Veterinary World, vol. 7, issue 4, 284-290.

Babaoglan M. and Kutlu H.R., 2008, Comparison of bio-activity of different thymol and carvacrol sources recommended for use as growth stimulant in broiler chickens nutrition. V. National Animal Nutrition Congress, Namık Kemal Univ. And Animal Nutrition Science Society, Proceedings of 254-260.

Babaoglan M., 2008, Comparison of bio-activities of different thymol and carvacrol sources suggested to be used as growth stimulant in broiler chickens, M.Sc. Thesis, Institute of Science and Technology, Volume: 18-3, 73.

Bravo D., Utterback P. and Parsons C. M., 2011. Evaluation of a mixture of carvacrol, cinnamaldehyde, and capsicum oleoresin for improving growth performance and metabolizable energy in broiler chicks fed corn and soybean meal, J. Appl. Poult. Res. 20: 115-120.

Bulgurlu S. and Ergül M., 1978, Physical, Chemical and Biological Analysis Methods of Feeds, E.U. Printing House, No: 127, Izmir, 176.

Calislar, S., Gemci, I., and Kamalak, A., 2009. Effects of Orego-Stim ${ }^{\circledR}$ on broiler chick performance and some blood parameters. J. Anim. Vet. Adv. 8:2617-2620.

Can, H.Y., and Celik, T.H. 2008, The residue risk and use of antibiotic in poultry breeding, Veterinary review journal, 79(4): 35-40, 2008.

Catala Gregori, P., Mallet, S., Travel, A., Orengo, J. and Lessire, M., 2008, Efficiency of a prebiotic and a plant extract alone or in combination on broiler performance and intestinal physiology. Canadian Journal of Animal Science, 88 (4), 623-629.

Celikbilek A., Deniz G., Orman A., Gencoglu H. and Kara C., 2014, Effects of a combination of dietary organic acid blend and oregano essential oil (lunacompacid $\AA$ herbex dry) on the performance and clostridium perfringens proliferation in the lleum of broiler chickens, J. Biol. Environ. Scl., 8(22), 61-69.

Ceylan, N., Ciftci, İ., Ildiz, F., and Sogut, A., 2003. Effects of enzyme, growth promoter, probiotic and organic acid supplementation to broiler diets on performance and gut microflora, Journal of Agricultural Sciences, 9 (3) 320-326.

Dolekoglu Ozcicek C. 2003. Consumer quality preferences, attitudes against health risks, knowledge levels about nutrition composition in processed food products. TEAE, Publish No:105, Ankara.

Duarte KF., Junqueira O.M., Borges L.L., Rodrigues E., Filardi R.S., Praes M.F.F.M., Laurentiz A.C. and Domingues C.F., 2013, Performance, carcass traits, and body composition of broilers fed different linseed oil levels between 21 and 56 days of age, Brazilian Journal of Poultry Science, Vol. 15, No. 4, 55-60.

Eldeeb, M.A., Metwally, M.A., and Galal, A.E., 2006. The impact of botanical extract, capsicum (capsicum frutescence), oil supplementation and their interactions on the productive performance of broiler chicks. X I I European Poultry Conference, Verona, Italy.

Fotea L., Costăchescu E., Hoha G. and Leonte D., 2010, The effect of oregano essential oil (origanum vulgare 1) on broiler performance, Lucrări Ştiinţifice Seria Zootehnie, vol. 53, 253-256. 
Guernec A., Chevalier B. and Duclos M.J., 2004, Nutrient supply enhances both IGF-1 and MSTN mRNA levels in chicken skeletal muscle, Domestic Animal Endocrinolgy, 26:143-154.

Hashemipour H., Kermanshahi H., Golian A., Raji A. and Krimpen M.M. V., 2013, Effect of thymol + carvacrol by next enhance $150 \AA$ on intestinal development of broiler chickens fed cmc containing diet. Iranian Journal of Applied Animal Science, 3(3), 567-576.

Heck A., Metayer S., onagbesan O. and Williams J., 2003, mRNA expression of components of the IGF system and of GH and insülin receptors in ovaries of broiler breeder hans fed ad libitum or restricted from 4 to 16 weeks of age, Domestic Animal Endocrinology, 25:287-294.

Inci, H., Karakaya, E., Sengul, T., and Sogut, B. 2014. The Structure of Poultry Meat Consumption in Bingol, Turkish Journal of Agricultural and Natural Sciences 1(1): 17-24, 2014.

ISO, 1998a, International Organization for Standardization, Microbiology of food and animal feeding stuffs - Horizontal method for the enumeration of mesophilic lactic acid bacteria - Colony-count technique at 30 degrees C. http://www.iso.org, (Access date: 15.11.2014).

ISO, 1998b, International Organization for Standardization, Microbiology of food and animal feeding stuffs - Horizontal method for the enumeration of coagulase-positive staphylococci (Staphylococcus aureus and other species) - Part 1: Technique using Baird-Parker agar medium. http://www.iso.org, (Access date: 15.11.2014).

Jamroz, D., Wiliczkiewicz, A., Wertelecki, T., Orda, J. and Skorupinska, J. 2005, Use of active substances of plant origin in chicken diets based on maize and locally grown cereals. Br. Poult. Sci. 46: 485-493.

Kahraman Z. Herbal extracts and their usage in laying hen diets. Journal of poultry research. 2009. 8 (1): 34-41. ISSN:1302-3209.

Karadas F., Pirgozliev V., Rose S.P., Dimitrov D., Oduguwa O. and Bravo D., 2014, Dietary essential oils improve the hepatic antioxidative status of broiler chickens, British Poultry Science, 55:3, 329-334pp.

Kaya, A. 1996. The importance of red meat in nutrition. Ege University Agricultural Research Center Technical Bulletins: 28.

Khattak F., Ronchi A., Castelli P. and Sparks N., 2014, Effects of natural blend of essential oil on growth performance, blood biochemistry, cecal morphology, and carcass quality of broiler chickens, Poultry Science, $93: 132-137$.

Kim D.K., Lillehoj H.S., Lee S.H., Jang S. I. and D. Bravo, 2010, High-throughput gene expression analysis of intestinal intraepithelial lymphocytes after oral feeding of carvacrol, cinnamaldehyde, or Capsicum oleoresin, Poultry Science, 89 :68-81.

Kirkpinar F., Unlu H.B., Serdaroglu M. and Turp G.Y., 2014, Effects of dietary oregano and garlic essential oils on carcass characteristics, meat composition, colour, $\mathrm{pH}$ and sensory quality of broiler meat, British Poultry Science. Volume 55, 2014 - Issue 2.

Kita, K., Tomas, F. M., Owens, P. C., Knowles, S. E., Forbes, B. E., Upton, Z., Hughes, R. and Ballard, F. J., 1996, Influence of nutrition on hepatic IGF-I mRNA levels and plasma concentrations of IGF-I and IGF-II in meat-type chickens, J. Endocrinol., 149: 181-190.

Kucukyılmaz K., Catlı A.C. and Cinar M., 2012, The Effect of Dietary Essential Oil Mixture Supplementation on the Broiler Performance, Carcass Yield and Some Internal Organ Weight. Kafkas Univ Vet Fak Derg. 18 (2): 291-296pp.

Langhout, P., 2000, New additives for broiler chickens, World poultry, 16: 22-27.

18 | $\mathrm{P}$ a g e

www.iiste.org 
Lee K.W., Everts H., Kappert H.J., Yeom K.H., and Beynen A.C. 2003a. Dietary carvacrol lowers body weight gain but improves feed conversion in female broiler chickens. J. Appl. Poult. Res., 12: 394-399.

Lee K.W., Everts H., Kappert H.J., Frehner M., Losa R., and Beynen A.C. 2003b. Effects of dietary essential oil components on growth performance, digestive enzymes and lipid metabolism in female broiler chickens. J. Appl. Poult. Res., 44:450-457.

Lee K.W.,. Everts H, Kappert H.J. and Beynen A.C., 2004, Growth performance of broiler chickens fed a carboxymethyl cellulose containing diet with supplemental carvacrol and/or cinnamaldehyde, International Journal of Poultry Science, 3 (9): 619-622.

Lu F.Z., Chen J., Wang X.X. and Liu H.L., 2009, Investigation of the Insulin-like Growth Factor System in Breast Muscle during Embryonic and Postnatal Development in Langshan andArbor Acres Chickens Subjected to Different Feeding Regimens. Asian-Aust. J. Anim. Sci. Vol. 22, No. $4: 471-482$.

MacKinnon K.M., He H., Nerren J.R., Swaggerty, C.L., Genovese K.J. and Kogut M.H., 2009. Expression profile of toll-like receptors within the gastrointestinal tract of 2-day-old Salmonella enteriditis-infected broiler chickens. Veterinary Microbiology 137 (2009) 313-319.

Mukhtar M.A., 2011, The effect of dietary clove oil on broiler performance, Australian Journal of Basic and Applied Sciences, 5(7): 49-51.

Nafaji P. and Torki M., 2010, Performance, blood metabolites and immunocompetaence of broiler chicks fed diets included essentioal oils of medicinal herbs, Journal of Animal and Veterinary Advances, 9(7): 1164-1168.

Naumann C. and Bassler R., 1993, Chemical analyses of feedstuff, Method Book III. 3rd ed., VDLUFA Press, Darmstad, Germany.

Nevvcomb, M.D., 1999, Herbs as a source of nutrition versus herbs as a source of drugs: A matter of claims, biology and regulations. Biotechn. In the feed industry. Proc. of Alltech's 15th Annu. Symp. 1999. Nothingham University Pres. Nicholasville, KY. P: 295-300.

NRC. Nutrient requirements of poultry: Ninth revised edition. 1994. National Academy Press. Washing, D.C., USA.

QIAGEN, 2013, Sample \& Assay Technologies, RT² profiller PCR array handbook, 3-63pp.

Saad N.Y., Mullerb C.D. and Lobstein A., 2013, Major bioactivities and mechanism of action of essential oils and their components, Flavour Fragr. J., 28, 269-279.

Shanoon A.K., Jassim M.S., Amin Q.H. and Ezaddin I.N., 2012, Effects of ginger (zingiber officinale) oil on growth performance and microbial population of broiler ross 308 , International Journal of Poultry Science, 11 (9): 589-593.

Sharifi, S.D., Khorsandi S.H., Khadem A.A., Salehi A. and Moslehi H., 2013.The effect of four medicinal plants on the performance, blood biochemical traits and ileal microfl ora of broiler chicks, Vet. Arhiv. 83, 69-80.

Simsek U.G, Guler T., Ciftci M., Ertas O.N., and Dalkilic, B. 2005. The Effect of an Essence Oil Mix (Derived from Oregano, Clove and Anise) on Body Weight and Carcass Characteristic in Broiler. Yüzüncü Y1l Üniversity faculty of veterinary journal, 16: 1-5.

SPSS, 2012, PASW Statistics for Windows, Version 21.0. Chicago: SPSS Inc. 
TSI, 1994, Turkish Standardization Institute, Determination of metabolic (convertible) energy in animal feed. TSE No: 9610, Ankara. . https://intweb.tse.org.tr, (Date of access: 15.11.2014).

TSI, 2005a, Turkish Standardization Institute, Microbiolgy of food and animal feeding stuffs Horizontal method for detection of Salmonella spp. https://intweb.tse.org.tr, (Date of access: 15.11.2014).

TSI, 2005b, Turkish Standardization Institute, Microbiology of food and animal feeding stuffs Horizontal method for enumeration of Clostridium perfringens - Colony-count technique (ISO/FDIS 7937:2004) / Note: Intended as replacement for EN 13401 (1999-04). https://intweb.tse.org.tr, (Date of access: 15.11.2014).

Viktorija M., Liljana K.G., Tatjana R., Ana C. and Rubin G., 2014, Antioxidative effect of capsicum oleoresins compared with pure capsaicin, IOSR Journal of Pharmacy, Volume: 4, Issue: 11, 4448.

Xu J., Zhou F., Ji1 B.P., Pei1 R.S. and Xu N., 2008, The antibacterial mechanism of carvacrol and thymol against Escherichia coli, Letters in Applied Microbiology, 47, 174-179.

Yagmur, C., and Gunes, E. 2010, Examination of food production and consumption in terms of a balanced diet in Turkey, VII. Agricultural Engineering Technical Congress, 11-15 January, Ankara.

Yildiz C.H., 2007, Effects of plant extracts containing carvacrol, tymol and rosmarinic acid on performance, digestive tract histomorphology and blood parameters of broilers. M.Sc. Thesis, Institute of Science and Technology, Trakya Univ. Volume: 18-3, 73.

Yossa N., Patel J., Macarisin D., Millner P., Murphy C., Bauchan G., and Lo Y.M., 2012, Antibacterial activity of cinnamaldehyde and sporan against Escherichia coli O157:H7 and Salmonella, Journal of Food Processing and Preservation ISSN 1745-4549.

Zhou F., JI B., Zhang H., Jiang H., Yang Z., LI J., Jihai LI J. and Yan W., 2007, The antibacterial effect of cinnamaldehyde, thymol, carvacrol and their combinations against the foodborne pathogen salmonella typhimurium Journal of Food Safety, 27, 124-133. 